\title{
Ecological study of the bird community of the broad-leaved deciduous forest of central Japan
}

\author{
Masanori Uramoto*
}

\section{Content}

Introduction

I. The study of the food consumption of birds

a) Some basic considerations

b) Feeding experiment on captive birds

i) Methods

ii) Results

c) Interspecific comparison of digestible energy

d) Faeces output and digestive coefficient

e) Food consumption of wild birds

f) Feeding habit and the food damaged

II. The ecological survey of a forest bird community

a) Description of the area

b) Breeding bird census

i) Method and the census area

ii) Results

c) Distribution pattern of some species

d) Feeding niches and feeding groups

III. A tentative estimation of the food consumption of the community

Acknowledgment

Summary

References

\section{Introduction}

A hundred years ago, Charles Darwin stated on the extremely entangled network in nature with the word "Web of Life" in his famous writing, "Origin of Species". Recently the essence of the meaning given by these words has been realized. The development of population ecology has clarified some of the natures of "Web of Life". On the other hand, limnology has given an impact to the study of "Web of Life". It is most remarkable in such a point that shows that the flow of energy and matter in a major habitat might behave as if there were sorne quantitative orderliness. If this orderliness becomes evident, and probably it may do so, the study of their flow will become one of the fundamental approaches in the study of "Web * Yamashina Inst. Orn. \& Zool., Shibuya, Tokyo (Formerly Dept. Biol., Fac. Sci., Tokyo Metropolitan Univ.) 
of Life". These two lines of investigation, population ecology and the study of the flow of energy and matter, will probably become interdependent with each other at near future. But at present they are going widely apart and the bridges between them are so few.

One of the bridges is the concept of food chain and food nexus. Food relation is one of the centering problems in population ecology, e.g., predator-prey relation, and is also one of the fundamental processes in the flow of energy and matter in the habitat. Actually some authors realize the importance of food relation in this respect, e.g., Elton and Miller (1954) and Macfadyen (1957).

In both lines of investigation the estimation of the amount of food consumption for each species population is of considerable value. But the direct measurement of food consumption of wild animals is usually very difficult. Up to the present but few investigations have been done about this. Therefore, the study of a community so far done has been limited in scope mainly to structural side or qualitative food relations in the community. In the terrestrial, especially forest, community this is more remarkable and few quantitative analyses of food relation in the forest has been made by now.

In this paper, bearing these circumstances in mind, the estimation of food consumption of wild birds was attempted firstly, next the breeding bird census and the spatial distribution of each species population of birds in a broad-leaved deciduous forest was described and finally the food consumption of the community was estimated.

\section{The study of the food consumption of birds}

\section{a) Some Basic Considerations}

The direct mesurement of food consumption of wild birds, which take a wide variety of foods and have great capacity for moving, is very difficult. Although the direct measurement in the field is necessary, since this task is so difficult at present, the approximate estimation can be given only by the measurement in laboratory for many species of birds. And it is necessary in future to measure the amount of food consumption in the laboratory where environmental conditions can be controlled at will. As under the field conditions the influences of various environmental factors are inseparably tangled, the effect of, at least some, factors should be analysed in the laboratory.

As regards the amount of the food consumption of captive birds many data are available (cf. Nice, 1938). The values are usually given in terms of fresh weight of food. But, as this will give different values for different food items, they are not comparable with one another. Furthermore, even if these amounts arc given in 
terms of dry weight of food, they are not comparable, for the proportion of the digestible part of food is different in different food items. Therefore, it is necessary to determine the digestive coefficient and to compare the amounts of digestible matter in dry weight with each other. To clarify the food relation in situ it is hoped to estimate the amount of food organisms consumed in terms of fresh weight. But comparing the amounts of different food or the amounts of food consumed by different species of different food habit with one another, the digestible matter in dry weight should be given. It is recommended to manifest these values in terms of calorific value, for the same amount of dry matter of different chemical composition may have different calorific content and, therefore, different significance in the metabolism of the bird. This expression in terms of calorific value is recommended also for the reason that this gives a fundamental knowledge for the study of the energy flow in the forest.

As to the energy budget in captive birds few reports have been published; on the physiology of migration (Wallgren, 1954; Rautenberg, 1957), on the effect of seasonal variation of environmental conditions (Kendeigh, 1944 and 1949; Seibert, 1949 ; Davis, 1955) and on the food consumption (Gibb, 1957). In the study of a community these information must be given for every, or at least for several dominant, constituent species populations. But as the species in which the energy budget has been studied are so few it has not been possible to perform the analytical study of a community based on the food relations and energy flow.

The relationship between basal metabolism and body size is well known as "surface law" for homoeotherms, and it seems that the food consumption of birds has the same type of relationship to the body size (Nice, 1938). If energy intake has any relationship to body size, it is possible to estimate, though roughly, the energy budget of the species not yet studied at present from the available information. For these purposes the feeding experiment was made on the three species of birds which differed in body size.

\section{b) Feeding Experiment on Captive Birds}

\section{i) Methods}

The birds investigated were Bengalee (Uroloncha domestica), Japanese Blue Magpie (Cyanopica cyanus japonica) and Carrion Crow (Corvus corone orientalis). Though Bengalee is not a wild bird but a domesticated small passerine origin of which is unknown, it was used for the reason that it could be kept with ease and was easily available. Bengalees used in the experiment were one male and two females, and they were kept in the wooden cages, $30 \mathrm{~cm}$ by $30 \mathrm{~cm}$ by $45 \mathrm{~cm}$, the frontal side of which was covered with wire-mesh. Females were held in one cage and a male in the other to prevent them from entering into the breeding state. Blue Magpie and 
Carrion Grow used were birds reared from nestlings sexes of which were unknown, and each was kept in a wire cage of $66 \mathrm{~cm}$ cube. Feeding experiments were also performed in these cages.

These cages were put in a room where environmental conditions were not controlled and the birds were kept under such climatic conditions as they were in outdoors. The floor of the cages was so prepared that they could be detached from the upper parts and was covered with a vinyl sheet replaced at the time of faeces collection. The insertion of the sheet made it easy to gather the remains of food and facces and to prevent the facces and/or paste food adhering to the floor of the cages.

Before the experiment, Bengalees had been fed on the mixtures of millet and great millet with various green leaves. During feeding trials the weighed amount of great millet only was given at the start of each trial, and the husks remained uneaten and the faeces were collected every one or two days. The faeces collected were often mixed with the husks and they were separated from each other as much as possible immediately after each collection. The faeces were dried in an oven at $80^{\circ} \mathrm{C}$ until their weight became constant, then weighed and kept in a calcium chloride desiccator as samples for the calorimetry. At the end of each trial, the duration of which was 6 to 10 days, the husks and the remaining grains were brought together and weighed.

Blue Magpie had been fed mainly on a sort of paste food, which consisted of two parts of mixtures of rice-bran and powdered rice, one part of grilled and powdered small fresh water fish and a bit of green leaves, mixed together with water in a small mortar, occasionally supplemented by bread, various fruits and so on. In the feeding trials two kinds of food were offered, paste food described above and silkworms. The paste food was made every day from the mixed powder and green leaves immediately before feeding. Before mixing these two materials, both were weighed and the dry weight was calculated from the proportion of their water content. The silkworms offered were at their fourth instar stage and given three or four times a day after weighing. The remaining food and the faeces were treated as the faeces of Bengalees.

Carrion Crow had been fed on small fresh horse-mackerel before and during the feeding trials. During the trials the fish were offered two times a day after weighing, and the remaining food and the faeces were treated every day in the same way as mentioned above.

The calorific values of the foods, the remains of foods and the faeces were determined by an adiabatic oxygen calorimeter, which was calibrated by benzoic acid. The limit of the accuracy of measurement was 1 cal for samples from Bengalees and Bluc Magpie and 3 cal for one from Carrion Crow.

The food intake was estimated as the difference between the calculated dry 
weight of the food offered and the dry weight of the food remained. And the digestible matter was estimated by the substraction of faeces weight from the food intake thus determined. The energy values were determined by the same procedure. ii) Results

The results of the feeding experiments are summarized in Tables 1,2 and 3 . The average body weight of the birds during feeding trials were $12.5 \mathrm{gm}$ for male and $13.5 \mathrm{gm}$ for female Bengalees, $83.0 \mathrm{gm}$ for Blue Magpie and $525 \mathrm{gm}$ for Carrion Crow.

As can be seen in the tables, there is considerable variation between trials in the food intake and the digestible food. The experimental technique used here was somewhat crude, but not so crude as to account for such variations. Evidently, it is better to control the environmental conditions, to employ more numbers of birds and to perform more extensive replications. But the present results seem to be sufficient for rough comparison of the energy requirement of various species of birds.

The amount of food consumed was 2.41 and $2.73 \mathrm{gm}$ dry weight per day for male and female Bengalee, respectively, and that of Blue Magpie was $11.76 \mathrm{gm}$ dry

Table 1. Summary of feeding trials on Uroloncha domestica
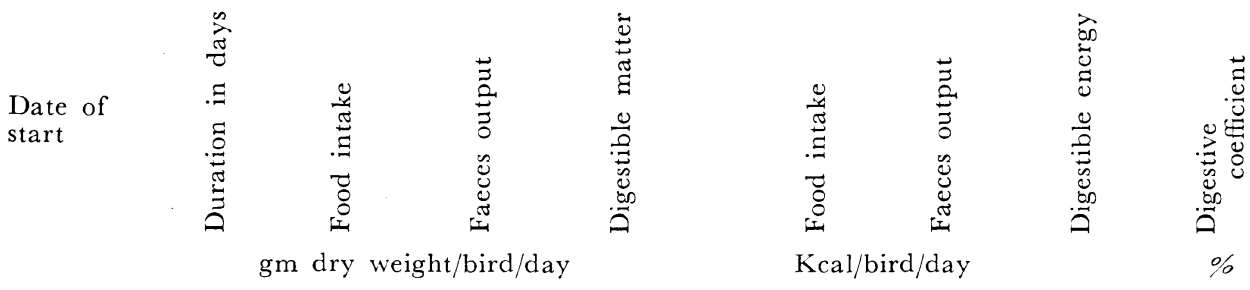

Male

$\begin{array}{lrrrrrrrr}\text { Jun. } 6 & 6 & 2.55 & 0.34 & 2.21 & 10.34 & 1.18 & 9.16 & 88.5 \\ \text { Jun. } 15 & 7 & 2.44 & 0.30 & 2.14 & 9.90 & 1.04 & 8.86 & 89.5 \\ \text { Jun. } 24 & 7 & 2.21 & 0.30 & 1.91 & 8.99 & 1.04 & 7.93 & 88.4 \\ \text { Sep. } 17 & 8 & 2.17 & 0.32 & 1.85 & 8.81 & 1.11 & 7.70 & 87.3 \\ \text { Sep. } 25 & 10 & 2.39 & 0.32 & 2.07 & 9.70 & 1.11 & 8.59 & 88.6 \\ \text { Oct. } 5 & 6 & 2.84 & 0.29 & 2.55 & 11.52 & 1.01 & 10.51 & 91.2 \\ \text { Average } & & 2.41 & 0.31 & 2.10 & 9.78 & 1.08 & 8.70 & 88.9\end{array}$

Female

$\begin{array}{lrrrrrrrr}\text { Jun. 6 } & 6 & 2.91 & 0.29 & 2.62 & 11.81 & 1.01 & 10.80 & 91.3 \\ \text { Jun. 15 } & 7 & 2.69 & 0.37 & 2.32 & 10.91 & 1.29 & 9.62 & 88.2 \\ \text { Jun. 24 } & 7 & 2.66 & 0.35 & 2.31 & 10.79 & 1.22 & 9.57 & 88.7 \\ \text { Sep. 17 } & 8 & 2.66 & 0.35 & 2.31 & 10.79 & 1.22 & 9.57 & 88.7 \\ \text { Sep. 25 } & 10 & 2.57 & 0.35 & 2.22 & 10.42 & 1.22 & 9.20 & 88.2 \\ \text { Oct. 5 } & 6 & 3.02 & 0.31 & 2.71 & 12.25 & 1.08 & 11.17 & 91.2 \\ \text { Average } & & 2.73 & 0.34 & 2.39 & 11.08 & 1.18 & 9.90 & 89.4\end{array}$


Table 2. Summary of feeding trials on Cyanopica cyanus

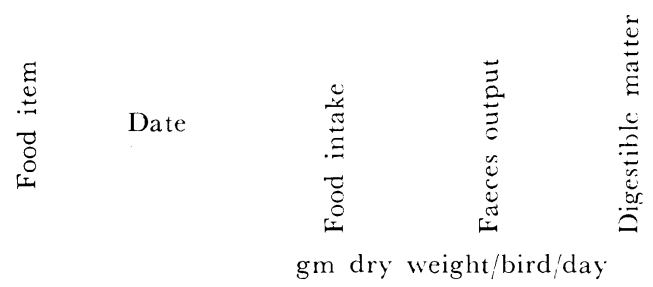

\begin{tabular}{|c|c|c|c|c|}
\hline \multirow{8}{*}{ 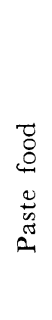 } & Mar. 13 & 13.70 & 7.84 & 5. 86 \\
\hline & Mar. 14 & 11.70 & 9.45 & 2. 25 \\
\hline & Mar. 15 & 11.25 & 6.35 & 4.90 \\
\hline & Mar. 21 & 11.50 & 6.80 & 4. 70 \\
\hline & Mar. 22 & 11.15 & 6.68 & 4.47 \\
\hline & Mar. 23 & $\ldots$ & 6.17 & $\ldots$ \\
\hline & Mar. 24 & 9.25 & 6.06 & 3. 19 \\
\hline & Mar. 25 & 13.95 & 8.32 & 5.63 \\
\hline \multirow{10}{*}{ 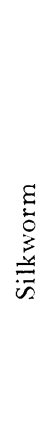 } & Mar. 26 & 11.60 & 6.43 & 5.17 \\
\hline & Average & 11.76 & 7. 18 & 4.52 \\
\hline & Sep. 15 & 10.66 & 3.25 & 7.41 \\
\hline & Sep. 16 & 11.99 & 4.64 & 7.35 \\
\hline & Sep. 17 & 20.45 & 5.70 & 14.75 \\
\hline & Sep. 18 & 16.79 & 4. 16 & 12.63 \\
\hline & Sep. 19 & 17.43 & 4.97 & 12.46 \\
\hline & Sep. 20 & 15.95 & 3.57 & 12. 38 \\
\hline & Sep. 21 & 12.85 & 3.49 & 9. 36 \\
\hline & Average & 15.16 & 4.25 & 10.91 \\
\hline
\end{tabular}

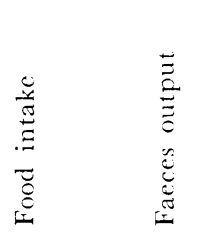

Kcal/bird/day

$\begin{array}{lllr}66.7 & 29.48 & 37.2 & 55.7 \\ 56.9 & 35.53 & 21.4 & 37.6 \\ 54.7 & 23.88 & 30.8 & 56.3 \\ 55.9 & 25.58 & 30.3 & 54.2 \\ 54.2 & 25.15 & 29.0 & 53.5 \\ - & 25.23 & - & - \\ 44.95 & 22.80 & 22.15 & 49.3 \\ 67.9 & 31.30 & 36.6 & 53.9 \\ 56.4 & 24.20 & 32.2 & 57.1 \\ 57.2 & 27.02 & 30.0 & 52.4 \\ 51.17 & 11.08 & 40.09 & 78.4 \\ 57.55 & 15.82 & 41.73 & 72.5 \\ 98.16 & 19.44 & 78.72 & 80.2 \\ 80.59 & 14.19 & 76.41 & 94.8 \\ 83.66 & 16.95 & 66.72 & 79.8 \\ 76.56 & 12.17 & 64.39 & 84.1 \\ 61.68 & 11.90 & 49.78 & 80.7 \\ 72.77 & 14.51 & 58.26 & 80.1\end{array}$

Table 3. Summary of feeding trials on Corrus corone

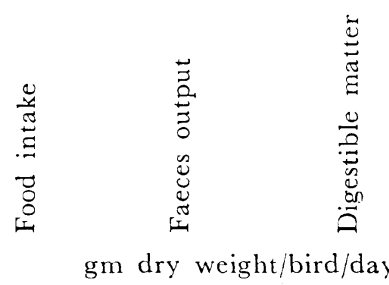

$\begin{array}{lrlll}\text { Nov. } 29 & 37.2 & 16.75 & 20.45 \\ \text { Dec. } & 1 & 34.4 & 9.0 & 25.4 \\ \text { Dec. } & 2 & 37.15 & 13.95 & 23.2 \\ \text { Dec. } & 8 & 46.4 & 16.25 & 30.15 \\ \text { Dec. } 9 & 48.35 & 20.35 & 28.0 \\ \text { Dec. } 15 & 27.45 & 14.05 & 13.4 \\ \text { Dec. } 16 & 36.5 & 16.6 & 19.9 \\ \text { Average } & 38.2 & 15.3 & 22.9\end{array}$

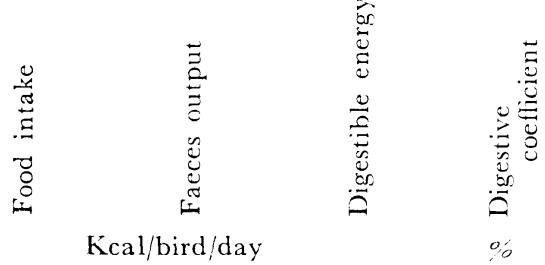

$\begin{array}{llll}214.6 & 45.4 & 169.2 & 78.8\end{array}$

$\begin{array}{llll}212.6 & 24.4 & 188.2 & 88.5\end{array}$

$\begin{array}{llll}229.8 & 37.8 & 192.0 & 83.6\end{array}$

$\begin{array}{llll}248.5 & 44.1 & 204.4 & 82.3\end{array}$

$\begin{array}{llll}284.6 & 55.2 & 229.4 & 80.6\end{array}$

$\begin{array}{llll}162.6 & 38.1 & 124.5 & 76.6\end{array}$

$\begin{array}{llll}197.1 & 45.0 & 152.1 & 77.2\end{array}$

$\begin{array}{llll}221.4 & 41.4 & 180.0 & 81.2\end{array}$ 
weight per day when it was fed on paste feed and $15.16 \mathrm{gm}$ when fed on silkworms. Carrion Crow consumed the food averaging $38.2 \mathrm{gm}$ dry weight per day.

\section{c) Interspecific Comparison of Digestible Energy}

As noted before, the interspecific comparison must be made on the digestible matter or, rather, energy, but these values are not given in most of the available data. Hence, there is no alternative except to compare the amount of food intake on many species of birds. Most of the data on food consumption so far given are expressed in terms of fresh weight, and, as noted previously, the comparison of food consumption in fresh weight is of little significance. The comparison of food intake in dry weight are less significant than that in digestible matter. But since the information concerning the amount of digestible matter are so few the dry matter intake was used here.

By plotting the data obtained in the experiment on logarithmic paper to the body weight together with other available data, we can see approximately linear distribution with some scattering (Fig. 1.). So, the equation $\mathrm{Y}=\mathrm{aWb}$ could be proposed to the relationship between food consumption and body weight. Two constants, $a$ and $b$, were calculated by the method of least squares and were 0.601 and 0.679 , respectively. Therefore the equation is $\mathrm{Y}=0.601 \mathrm{~W}^{0.670}$, or $\log \mathrm{Y}=0.679 \log \mathrm{W}-$ 0.321 , where food consumption ( $Y$ ) is expressed in terms of gm dry weight per day and body weight (W) in terms of gm fresh weight.

As to the amount of digestible energy, all data availble now are shown in table 4. These data were plotted on logarithmic paper to the body weight (Fig. 2). As

Table 4. Digestible energy of captive birds

Species

Bengalee (male) (Uroloncha domestica)

Bengalee (female) (Uroloncha domestica)

Blue Magpie (Cyanopica cyanus)

Blue Magpie (Cyanopica cyanus)

Carrion Grow (Corvus corone)

Brambling (Fringilla montifringilla)

House Sparrow (Passer domesticus)

House Sparrow (Passer domesticus)

Great Tit (Parus major)

Blue Tit (Parus caeruleus)

Coal Tit (Parus ater)

Coal Tit (Parus ater)

$\begin{array}{ccc}\begin{array}{c}\text { Body weight } \\ (\mathrm{gm})\end{array} & \begin{array}{c}\text { Digestible } \\ \text { energy } \\ \text { (Kcal/bird/day) }\end{array} & \text { Note } \\ 12.5 & 8.7 & \\ 13.5 & 9.9 & \\ 83.0 & 30.0 & \text { Fed on paste food } \\ 83.0 & 58.26 & \text { Fed on silkworm } \\ 525 & 180.0 & \\ 23.5 & 20.4 & \text { Rautenberg (1957) } \\ 25.1 & 20.6 & \text { average for 1954 } \\ 28.0 & 24.25 & \text { Davis (1955) } \\ 19.4 & 19.7 & \text { Fig. 1, 15 }{ }^{\circ} \\ 10.3 & 10.8 & \text { Gibb (1957) } \\ 8.8 & 11.75 & \text { Fed on mixed insect } \\ 8.4 & 9.3 & \end{array}$




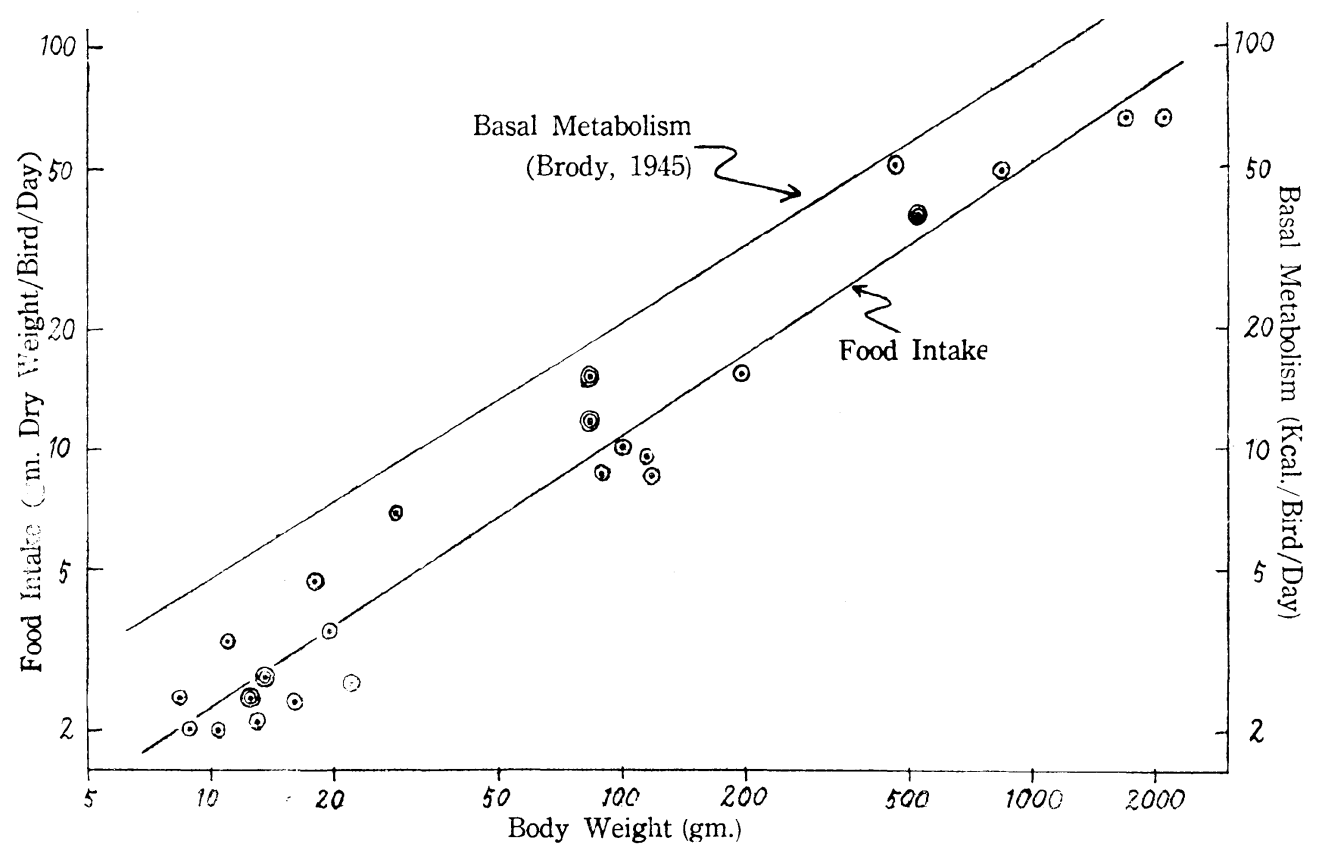

Fig. 1 Food intake and body weight. (Double circles show own data.)

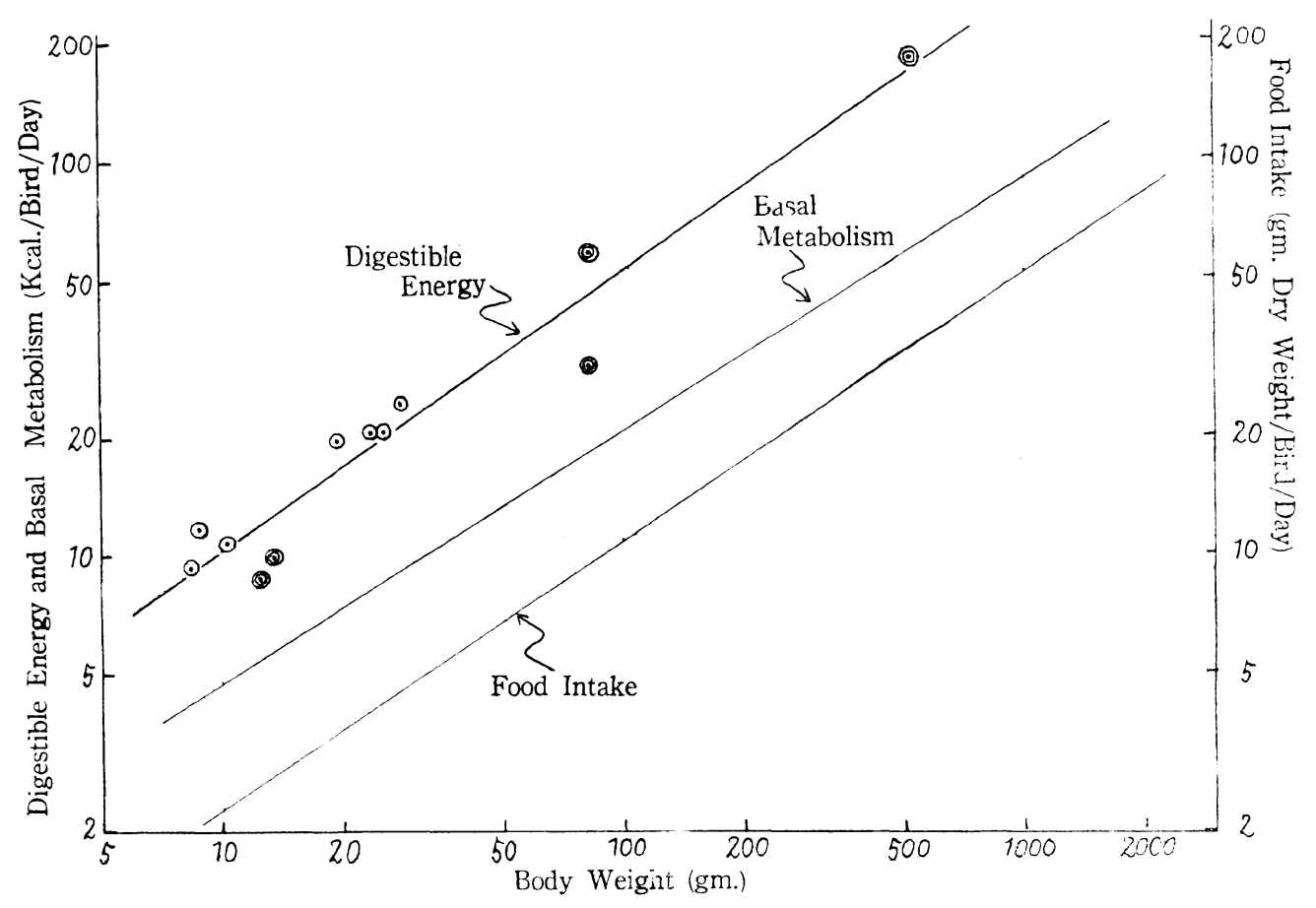

Fig. 2 Digestible energy and body weight. (Double circles show own data.) 
the number of the data were few, the linearity of the distribution of these data was less obvious than in the case of the dry matter intake. Nevertheless it is evident that the logarithm of the digestible energy must be in linear reation with the logarithm of the body weight. Repeating once more, first the linear relationship are known between the logarithm of the basal metabolism and that of the body weight (cf. Brody, 1945), secondly, as described above, the longarithm of the dry matter intake shows linear relationship to that of the body weight, thirdly for digestible energy has more close ralationship with the basal metabolism than the dry matter intake has, and finally and above all linear relationship was found between the logarithm of the digestible energy and that of the body weight, though it is less obvious.

Therefore, similar to the previous equation, $\mathrm{Y}=\mathrm{aW}$ could cover the data, where the digestible energy ( $\mathrm{Y}$ ) being expressed in terms of Kcal per day and the body weight $(W)$ in terms of gm fresh weight. Two constants, a and b, were calculated by the method of least squares and were 2.03 and 0.706 , respectively. Then. the equation is $\mathrm{Y}=2.03 \mathrm{~W}^{0.706}$, or $\log \mathrm{Y}=0.706-\log \mathrm{W}+0.307$.

Comparing these two equations, it was found that there existed a surprising accordance of the values of coefficient of $\log \mathrm{W}, \mathrm{b}$, with each other, which agreed with the corresponding coefficient, 0.62 to 0.70 averaging 0.64 , in the equation proposed to the relationship between the basal metabolism and the body weight in birds (Brody, 1945). It can not be considered at present that the coefficients of these equations should fall into the same value, but it is unlikely that such accordance is an accident. Therefore, it is possible to assume with fair justification that logarithm of the digestible energy must have a linear relationship with logarithm of the body weight.

The values of the digestible energy determined in this experiment and used in the interspecific comparison are not the true digestible energy used in the study of nutrition, because they are determined by the difference of energy intake and energy output in the faeces which contain not only the undigestible matter but also the metabolic waste products in birds. The undigestible matter and metabolic waste products, mainly uric acid, can not well be separated in birds. Furthermore, the digestible energy in strict sense may not be comparable precisely between different species, for the faeces contain not always all the undigestible matter and differ from unmetabolizable matter since some parts of undigestible matter may be lost in the process of rectal fermentation. Considering these circumstances, it is natural that the digestible energy thus determined should not have exactly the same relationship with the body weight with that between the basal metabolism and the body weight. Nevertheless it is also natural that the metabolizable energy should be roughly proportional to the digestible energy, and it is unnecessary that the linear relationship between logarithm of digestible energy and that of the body weight should be denied 
as an accident.

As can be seen in Fig. 2, the deviation of individual values from the theoretical line obtained by the equation thus determined is considerably large, but plotting the values of the basal metabolism on logarithmic paper to the body weight, the data show the scattering of about the same degree (cf. Brody, 1945). The deviations of these data must be ascribable at least partly to the deviations of the values of the basal metabolism, i.e., the species specific conditions. And it must also be ascribable partly to the differences between the environmental conditions, especially air temperature, at which the determination of the digestible energy has been performed, since the food intake and digestive coefficient are proved to be subjected to a considerable change from the changes of environmental conditions (Kendeigh, 1949; Seibert, 1949 ; Davis, 1955). It must also be ascribable partly to the difference of activity of each bird in the cage.

The fact that, although there are several factors causing these deviations, the digestible energy on the average has the same relationship with the body weight as the basal metabolism and dry matter intake have, suggests that as a first approximation the energy requirement of various species of birds should be conjectured by the equation $\mathrm{Y}=2.03 \mathrm{~W}^{0.706}$.

It may be possible to remove some of the causes of these deviations by the replicating the feeding experiment for more individuals, by the experiment using more species of birds and by controlling the environmental conditions, but the fact that there exists the relationship between the digestible energy and the body weight might not be denied and the coefficient of the equation might change slightly. $1 \mathrm{t}$ is hoped as the next step that by the more extensive experiments the species specific conditions causing the deviation from the equation and the relationship between the digestible energy and the digestive coefficient and various environmental factors are made clear as Kendeigh, Seibert and Davis have done.

\section{d) Faeces Output and Digestive Coefficient}

The amount of faeces output determined in the feeding experiment showed some variations as of food intake did (Tables 1, 2 and 3). The faeces output has some ecological significance in the forest, since it offers food matter to some microorganisms and accelerates the matter circulation in the forest, but since the amount of faeces output differs considerably in the digestibility of different food organisum, the relation between food organisms and its digestibility shall be considered here.

Bengalees kept on great millet diet showed digestive coefficient of about $90 \%$, Blue Magpie on silkworms about 80\% and Carrion Crow on horse-mackerel about $80 \%$. It is almost meaningless ecologically to compare the digestibility of paste food to them. The only available reference on digestive coefficient of various food organisms 
were given by Gibb (1957). These data were summarized in Table 5. There are so few data at present that any conclusion can not be drawn from them. But,

Table 5. Digestive coefficient of various food

\begin{tabular}{lcl}
\multicolumn{1}{c}{ Food } & $\begin{array}{c}\text { Digestive } \\
\text { coefficient, }(\%)\end{array}$ & \multicolumn{1}{c}{ Note } \\
Great millets & 89.2 & Bengalee \\
Silkworms & 80.1 & Blue Magpie \\
Horse-mackerel & 81.2 & Carrion Crow \\
Ground nuts & 80.4 \\
Scots-pine seeds & 78.6 \\
Sunflower seeds & 81.0 \\
Mealworms & 85.1 \\
Mixed insects & 66.7
\end{tabular}

in general, they suggest that the digestive coefficient are about $80 \%$ or more for insect larva and various seeds and nuts. The digestive coefficient of adult insects and spiders, which make up a considerable part of food in small birds, and other small animals, e.g., millipeds and earthworms, have been unknown by now. Only one feeding experiment, at which the adult insects were offered, was performed by Gibb (1957). He offered "mixed insects", consisting of $40.5 \%$ caterpillars, $17.5 \%$ weevils, $10 \%$ nabid bugs, $7 \%$ mirid bugs and $25 \%$ spiders, to a Coal Tit. The fact that this food showed the digestive coefficient of about $67 \%$ suggests that the digestibility of adult insects and spiders are unexpectedly low. But, as he expressed the composition of "mixed insects" in numbers and not in weight, the more precise figure can not be known.

In relation to this point Gibb said that it was surprising that the metabolizable energy had varied so much, and the food intake so little. In fact the dry matter intake was only slightly higher when the birds fed on "mixed insects" than on seeds or mealworms. There is a corresponding case with this in the feeding experiment on Blue Magpie. Though the digestive coefficient of the paste food was very low (about 50\%), the food intake was rather fewer when the bird fed on the paste food than on silkworms. As the volumes of food consumed were about the same in both foods, it may be suggested that there is a maximum volume in food consumption in birds and, even when the food has low digestive coefficient, the food intake can not exceed this volume. It is probable that the appetite of birds may diminish when they take a large volume of food, irrespective of its digestibility.

This suggestion is of great importance in ecological problems. For, even if food organisms are abundant, the digestible energy and matter may not be sufficient for the requirement of birds and the birds may become weak when the food organisms 
have low digestibility. The suggestion that the digestibility of adult insects and spiders may be low is of considerable importance in this connection. And the digestive coefficient of adult insects and other small animals, which are important food for birds, must be determined at near future.

\section{e) Food Consumption of Wild Birds}

The ultimate goal of the measurement of food consumption of captive birds here is the estimation of the food consumption of wild birds. Though the food consumption of the wild birds have been considered to be higher than that of captive birds, the precise figure of the difference between the food consumptions of the wild and captive birds is unknown. As Lack (1954) pointed out, the food consumption of wild birds have been investigated on few species and all but one species so far investigated were non-passerine larger birds.

Pynnönen (1939) estimated the consumption of conifer seeds by Great Spotted Woodpecker, Dendrocopos major, in the winter and found that it took $0.8 \mathrm{gm}$ of seeds or $3.5 \mathrm{Kcal}$ of food per hour. This corresponds to $4.8-9.0 \mathrm{gm}$ of seeds or $21-40$ Kcal of food per day in winter (the bird itself weighs about $90 \mathrm{gm}$ ).

Gibb (1956) observed feeding behaviour of a Rock Pipit, Anthus spinoletta, (about $22 \mathrm{gm}$ ) in the winter and estimated the food intake about $30 \mathrm{Kcal}$ per day and the digestible energy about $12 \mathrm{Kcal}$ per day. Although there is no corresponding data on food consumption of these two species in captivity, comparing these with the values calculated by the equation described before, it is evident that these estimations are rather low. They may probably be underestimated. Considering that the food intake was so high (about $26 \mathrm{gm}$ dry weight of periwinkle or about $6 \mathrm{gm}$ dry weight of organic matter) and the digestive coefficiert was so low (about 40\%), Rock Pipit in the winter might be in condition as noted before, that is the bird might take the maximum volume of food it could take.

Southern (cf. Lack, 1954) counted the rodents brought by male Tawny Owl, Strix aluco, to incubation female and showed that the female received about $70 \mathrm{gm}$ of rodents per day or about onc-sixth of the weight of the bird. This is about the same amount as that calculated by the equation mentioned before and it is reasonable because the incubating female is even more inactive than captive birds.

Fitch et al. (1946) observed the feeding activity of a Red-tailed Hawk, Buteo jamaicensis, for 21 days and found that it took about $100 \mathrm{gm}$ of food per day. The same species took $140 \mathrm{gm}$ of food daily in captivity. So, in this case the wild bird took less food than captive one did. But the amount of food taken was less reliable, since their observation did not continue successively.

Recently, two othere investigations on the food consumption of wild birds were published. Watson (1957) investigated the food ecology of Snowy Owl, Nyctea scan- 
diaca, in breeding season and found that a male ate about $320 \mathrm{gm}$ of lemmings and gave $240 \mathrm{gm}$ to each of two females, and the other male ate about $280 \mathrm{gm}$ and brought $220 \mathrm{gm}$ to his mate. A pair of this speies ate about $360 \mathrm{gm}$ of mice and rats in captivity. Its male weighs about $1700 \mathrm{gm}$ and its female about $2100 \mathrm{gm}$ on an average. In this species wild bird ate about $20-80 \%$ more food than captive bird did.

Drinnan (1957 \& 1958) investigated the food consumption of Oystercatcher, Haematopus ostralegus, (about $460 \mathrm{gm}$ ) in the field and in the laboratory. He estimated that the captive bird ate $250 \mathrm{ml}$ or $68 \mathrm{gm}$ dry weight per day, while the wild bird took $395 \mathrm{ml}$ or $106 \mathrm{gm}$ dry weight per day, about 56\% more than captive bird. These two investigations show that wild birds may take about $50-60 \%$ more food than captive birds do, and that they often may take less than $150 \%$ of food intake of captive birds.

Kendeigh (1949) assumed that the digestible energy requirement determined at the lowest air temperature that the bird could endure in captivity was attained at higher temperature if the bird required more energy for activity at the latter. This value was about $60 \%$ higher than the energy requirement of captive bird at $15^{\circ} \mathrm{C}$. And, in the case of man, it is considered in the study of energy metabolism that man at work requires about 30-50\% more energy than that required by one at rest.

After all, the energy requirement of wild birds are almost unknown at this time, but probably it may tentatively be assumed that they will require about $30-50 \%$ more energy than captive birds do. Although the estimation of energy requirement of wild birds by this assumption and by the equation described before is naturally very crude, at present it is only approach to the quantitative study of food relation of birds in a forest.

\section{f) Feeding Habit and the Food Damaged}

The energy requirement of the wild bird may be conjectured by the way described above, and the energy intake may be guessed by this and the digestive coefficient of food organisms. But the food intake may or may not agree with the amount of prey organisms damaged, which is often more important ecologically than the amount of food actually taken.

Blue Magpie, when given silkworms of fourth instar stage, first decapitated the prey and at that time a part of the alimentary canal of the prey was often thrown away with the head. Next it brandished the prey violently and much of the content of the alimentary canal and some viscera were scattered, then it tore the remainder to three or four pieces and swallowed them. Of course, Blue Magpie swallowed a smaller insect, e.g.. mealworm, wholly. Bengalee husked the great millet and swallowed the kernel only, as most finches do. Carrion Crow fed on the horse-mackerel ate at first the viscera and did not take the bony part, e.g., the head, the tail and 
the fins.

Because of these feeding habits the food intake not always agrees with the lood killed or damaged. It is a problem of considerable importance to estimate the predatory pressure of birds to a certain species of animals and it may be estimated by considering the food intake of predator species. But it must be noted that an unexpected result may arise from the feeding habit of the predator.

\section{The ecological survey of a forest bird community}

In Japan the ecological study of the forest birds, or rather almost erery bird, has not been made. It is necessary at present to make a general survey of the various forest bird communities prior to the analytical study. At first, the ecological survey of a breeding bird community of a broad-leaved deciduous forest in central Japan was carried out in 1957 and 1958. In this part of the paper the brecding bird census and some spatial distribution of birds will be described.

\section{a) Description of the Area}

The area studied lies at the eastern part of Chichibu-Tama National Park, the drainage area of Nippara River, which is a tributary of Tama River flowing eastward into Tokyo Bay (Fig. 3). It is a steep calcareous mountain region reaching up to
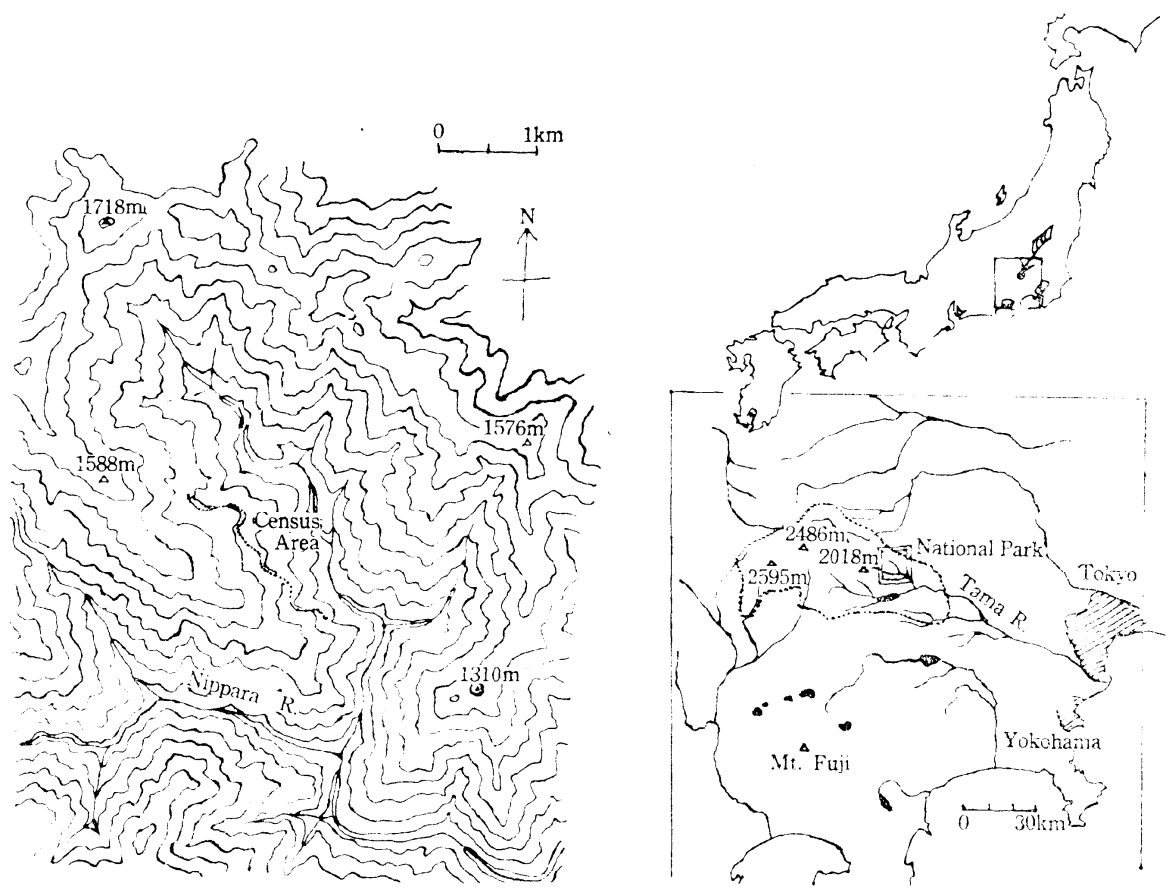

Fig. 3 The maps of the census area 
about $2000 \mathrm{~m}$ above sea level. Above about $800 \mathrm{~m}$ in altitude there is a broad-leaved deciduous forest dominated by Fagus crenata and F. japonica on slopes up to about $1600-1700 \mathrm{~m}$. Above there the subalpine coniferous forest grows. This broad-leaved deciduous forest region was chosen as the study area.

In this region a vegetation pattern which is due mainly to physiographic and edaphic conditions can be seen. Usually the dominant species on slopes are Fagus spp. associated with Acer spp., Carpinus carpinoides and so on. Occasionally Betula spp. or Quercus crispula may be dominant species on sunny slopes. On small ridges where large rocks are exposed and soil is shallow, Tsuga Sieboldii is the dominant species. Along the valleys and ravines the $\mathrm{d}$ minant species is Fraxinus cammemoralis associated with Acer spp., Plerocarya rhoifolia and so on. Understories are generally sparse, especially on ridges, and are consisted of Acer spp., Clethra barbinervis and so on.

Shrub layer is dominated by bomboo-grass (Sasa purpurascens), and it grows so dense that man can hardly walk about in the forest. But in some places, especially the heads of gullies, there is no undergrowth except sparse herbs, and where Tsuga Sieboldii dominates there are some Rhododendron diatatum instead of bamboo-grasses. And underparts of the slopes where Fraxinus commemoralis usually dominates, and steeper slopes where soil is cosiderably shallow, are also lacking of bamboo-grasses or have very poor growth of them. The floor of the forest along the ravines is usually covered with some ferns. The plant sociological study of this region has been carried out by Maeda and Yoshida (195!)

\section{b) Breeding Bird Census}

i) Method and the Census Area

In the study area the slope is so steep and bamboo-grasses grow so dense that it is difficult to cover a large area without disturbing birds and without mountaineering. Therefore initial plan to make a territory mapping in a quadrat area had to be abandoned, and a belt census method was adopted.

Gensus arca was chosen along a pathway which traverses a slope facing northeastward. Marks were put on tree trunks at about $25 \mathrm{~m}$ interval grid so as to include the pathway in the grid. Territory mapping was made on all individuals which were heard or seen and were able to be plotted on the map. The width of the belt was determined accurding to the distance at which each species of birds was able to be identified, based on the mapping data when the census work was over. An example of the census map was shown in Fig. 4. The width of the belt thus determined and the area covered were shown for each species as "identification distance" and "census area" in Table 6. Census work was carried out in late April to early June in 1957 and 1958. Most of the census trips were made before noon, 


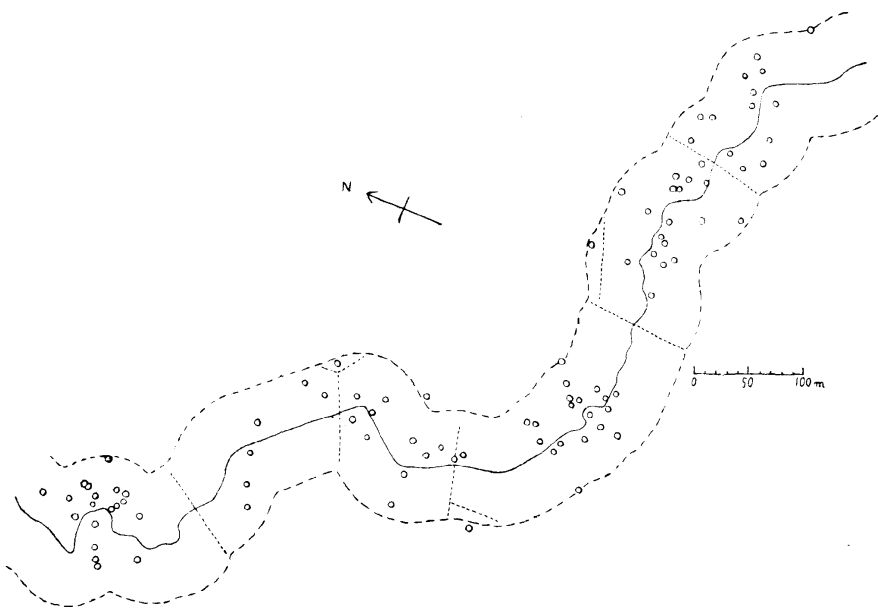

Fig 4. A part of the census map for Great Tit, Parus major, showing the identification distance and the width of the census area. Dotted lines show the boundaries of the territories.

mainly from dawn to 10:00 a.m., but some were made in the afternoon.

Census belt was $2750 \mathrm{~m}$ long, and began about $900 \mathrm{~m}$ and ended about $1200 \mathrm{~m}$ in altitude. In the census area there were all vegetation patterns described beforc. The height of the dominant trees was $18-20 \mathrm{~m}$ and that of sparse understory was $8--10 \mathrm{~m}$. Shrub layer mainly consisted of bamboo-grasses was up to $1.5 \mathrm{~m}$ high in upper-parts of the area, but in underparts of the area this was rather sparse and $1.0-0.5 \mathrm{~m}$ high or lacking entirely. There were three places where Tsuga Sieboldii dominated, and several gullies and one ravine in the area. Generally the forest floor was covered with dense litter, many dead branches and twigs and some fallen trees, but in rocky small ridges and gullies soil was shallow and dead leaves had been blown off. The features of the census area in early spring are shown in Plates 1 and 2.

ii) Results

The results of the census are shown in Table 6 .

The census figures are relatively reliable for small birds but may be rather inaccurate for larger species. The shape of the census area was very narrow belt and it was not enough to cover the territories of larger birds. Particularly, Hymalayan Guckoo, Cuculus saturatus, was seen frequently, but its density could not be determined by the method used here. The densities of six larger species, i.e., Copper Phcasant, Phasianus soemmerringii, Japanese Green Pigeon, Sphenurus sieboldii, Jay, Garrulus glandarius, White-backed Woodpecker, Dendrocopos leucotos, Great Spotted Woodpecker, Dendsocopos major, and Japanese Green Woodpecker, Picus awokera, may be overestimated. Although the error in the densities of larger species would cause rather large errors in the relative figures of biomass and food consumption 
Table 6. Species composition and size of population

\begin{tabular}{|c|c|c|c|c|c|c|c|c|}
\hline Species & $\begin{array}{l}\text { Identification } \\
\text { distance } \\
(\mathrm{m})\end{array}$ & $\begin{array}{l}\text { Census } \\
\text { area } \\
\text { (ha) }\end{array}$ & $\begin{array}{l}\text { Nun } \\
\text { of } p \\
1957\end{array}$ & $\begin{array}{l}\text { nber } \\
\text { pairs } \\
1958\end{array}$ & $\begin{array}{r}(\mathrm{pa} \\
1957\end{array}$ & $\begin{array}{r}\mathrm{De} \\
\left./ \mathrm{km}^{2}\right) \\
1958\end{array}$ & $\begin{array}{l}\text { ensity } \\
\text { (pairs/100 } \\
1957\end{array}$ & $\begin{array}{r}\text { acres) } \\
1958\end{array}$ \\
\hline $\begin{array}{l}\text { Crowned Willow Warbler } \\
\text { (Phylloscopus occipitalis) }\end{array}$ & 60 & 33.4 & 15 & 15 & 45 & 45 & 18 & 18 \\
\hline $\begin{array}{l}\text { Pale-legged Willow Warbler } \\
\text { (Phylloscopus tenellipes) }\end{array}$ & 50 & 27.6 & 1 & 6 & 4 & 22 & 2 & 9 \\
\hline Great Tit (Parus major) & 50 & 27.6 & 13 & 14 & 47 & 51 & 19 & 21 \\
\hline Coal Tit (Parus ater) & 55 & 30.7 & 8 & 26 & 26 & 85 & 11 & 34 \\
\hline Varied Tit (Parus varius) & 50 & 27.6 & 6 & 10 & 22 & 36 & 9 & 15 \\
\hline Willow Tit (Parus atricapillus) & 50 & 27.6 & 6 & 10 & 22 & 36 & 9 & 15 \\
\hline $\begin{array}{l}\text { Long-tailed Tit } \\
\text { (Aegithalos caudatus) }\end{array}$ & 35 & 19.3 & 3 & 6 & 16 & 31 & 6 & 13 \\
\hline Bush Warbler (Cettia diphone) & 45 & 24.9 & 11 & 9 & 44 & 36 & 18 & 15 \\
\hline $\begin{array}{l}\text { Short-tailed Bush Warbler } \\
\text { (Urosphena squameiceps) }\end{array}$ & 40 & 22.1 & 9 & 8 & 41 & 36 & 17 & 15 \\
\hline $\begin{array}{l}\text { Narcissus Flycatcher } \\
\quad \text { (Muscicapa narcissina) }\end{array}$ & 70 & 39.0 & 12 & 16 & 31 & 41 & 13 & 17 \\
\hline $\begin{array}{l}\text { Brown Flycatcher } \\
\quad \text { (Muscicapa latirostris) }\end{array}$ & 40 & 22.1 & 1 & 2 & 5 & 9 & 2 & 4 \\
\hline $\begin{array}{l}\text { Blue Flycatcher } \\
\text { (Muscicapa cyanomelana) }\end{array}$ & 45 & 24.9 & 2 & 2 & 8 & 8 & 3 & 3 \\
\hline Nuthatch (Sitta europeae) & 65 & 36.2 & 7 & 8 & 19 & 22 & 8 & 9 \\
\hline $\begin{array}{l}\text { Pigmy Woodpecker } \\
\text { (Dendrocopos kizuki) }\end{array}$ & 40 & 22.1 & 6 & 5 & 27 & 23 & 11 & 9 \\
\hline $\begin{array}{l}\text { Great Spotted Woodpecker } \\
\text { (Dendrocopos major) }\end{array}$ & 70 & 39.0 & 1 & 2 & 3 & 5 & 1 & 2 \\
\hline $\begin{array}{l}\text { White-backed Woodpecker } \\
\text { (Dendrocopos leucotos) }\end{array}$ & 70 & 39.0 & 2 & 1 & 5 & 3 & 2 & 1 \\
\hline $\begin{array}{l}\text { Japanese Green Woodpecker } \\
\text { (Picus awokera) }\end{array}$ & 70 & 39.0 & 2 & 1 & 5 & 3 & 2 & 1 \\
\hline $\begin{array}{l}\text { Japanese Green Pigeon } \\
\text { (Sphenurus sieboldii) }\end{array}$ & 60 & 33.4 & 1 & 1 & 3 & 3 & 1 & 1 \\
\hline Jay (Garrulus glandarius) & 50 & 27.6 & 4 & 5 & 15 & 18 & 6 & 7 \\
\hline $\begin{array}{l}\text { House Wren } \\
\quad \text { (Troglodytes troglodytes) }\end{array}$ & 50 & 27.6 & 8 & 5 & 28 & 18 & 12 & 7 \\
\hline Blue Robin (Erithacus cyane) & 65 & 36.2 & 23 & 29 & 64 & 80 & 26 & 32 \\
\hline $\begin{array}{l}\text { Japanese Robin } \\
\text { (Erithacus akahige) }\end{array}$ & 55 & 30.7 & - & 1 & - & 3 & - & 1 \\
\hline $\begin{array}{l}\text { Siberian Ground Thrush } \\
\quad \text { (Turdus sibiricus) }\end{array}$ & 70 & 39.0 & 2 & 2 & 5 & 5 & 2 & 2 \\
\hline $\begin{array}{l}\text { Brown Thrush } \\
\text { (Turdus chrysolaus) }\end{array}$ & 70 & 39.0 & 2 & 2 & 5 & 5 & 2 & 2 \\
\hline $\begin{array}{l}\text { Golden Mountain Thrush } \\
\quad \text { (Turdus dauma) }\end{array}$ & 70 & 39.0 & 2 & 1 & 5 & 3 & 2 & 1 \\
\hline $\begin{array}{l}\text { Copper Pheasant } \\
\text { (Phasianus soemmerringii) }\end{array}$ & 40 & 22.1 & 2 & 2 & 9 & 9 & 4 & 4 \\
\hline
\end{tabular}


Hymalayan Cuckoo
(Cuculus saturatus)

Scops Owl (Otus scops)

Hawk Eagle

(Spizaëtus nipalensis)

Total 29 species

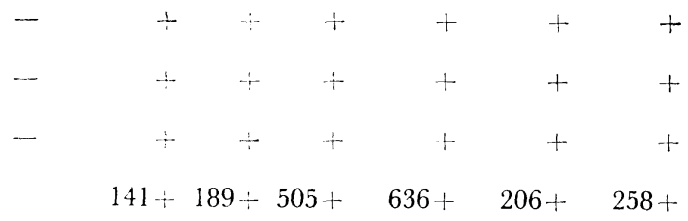

Note: Brown-eared Bulbul (Hypsipetes amaurotis) and Ashy Minivet (Pericrocotus roseus) rarely visited this forest from lower habitat. and two colonies of House Martin (Delichon urbica) existed at about $2 \mathrm{~km}$ distant rocky precipices from the census area.

estimated later, there was no way to correct the figures of their densities.

Total densities of breeding pairs was $505+$ pairs per square $\mathrm{km}(206+$ pairs per 100 acres) in 1957 and $636+$ pairs per square $\mathrm{km}(258+$ pairs per 100 acres $)$ in 1958. There is no comparable datum of densities of Japanese forest birds with them. In the deciduous forest of eastern North America, where the vegetation type is resembling to that of the study area, total density of breeding pairs is similar to these results, e.g., 206-271 averaging 239 pairs per 100 acres (Williams, 1936), 221 pairs per 100 acres (Kendeigh, 1944b) and so on.

It is hoped to express the results of census in bimass values in order to analyse the roll of each species population and the roll of bird community in the forest, as has been pointed out by Turček (1948/51) and Salt (1957). There is no reliable datum published on the body weight of Japanese birds, and here the data reported by Enomoto (1941) were used, though they were not so reliable. The biomass figures are shown in Table 7 together with the body weight of each species.

The biomass of each species population was calculated on the assumptions that every species was monogamous and unmated individuals did not present. But as some species, at least Copper Pheasant, might be polygamous and there must have been some unmated individuals, the biomass figures, and hence the values of the food consumption and energy requirement estimated on the basis of these figures in the later part of this paper, would be underestimated.

Total biomass was $43.5 \mathrm{~kg}$ per square $\mathrm{km}(17.6 \mathrm{~kg}$ per 100 acres) in 1957 and $45.8 \mathrm{~kg}$ per square $\mathrm{km}(18.5 \mathrm{~kg}$ per 100 acres $)$ in 1958.

Wing (1956) gave the total biomass value of birds for some deciduous forests of eastern North America and they were $4.4 \mathrm{~kg}$ per 100 acres for oak-hickory, $4.6 \mathrm{~kg}$ per 100 acres for oak-maple, $7.0 \mathrm{~kg}$ per 100 acres for lowland beech-maple and $8.3 \mathrm{~kg}$ per 100 acres for climax beech-maple forest. Salt (1957) calculated the total biomass values for several bird census data and they were $9.0 \mathrm{~kg}$ per 100 acres for hemlockbeech, $8.9 \mathrm{~kg}$ per 100 acres for beech-maple-hemlock, $9.0 \mathrm{~kg}$ per 100 acres for beechmaple-pine and $11.2 \mathrm{~kg}$ per 100 acres oak-hickory forest.

Comparing these data with that of the community, it is remarkable that the total 
Table 7. Standing biomass of each species population

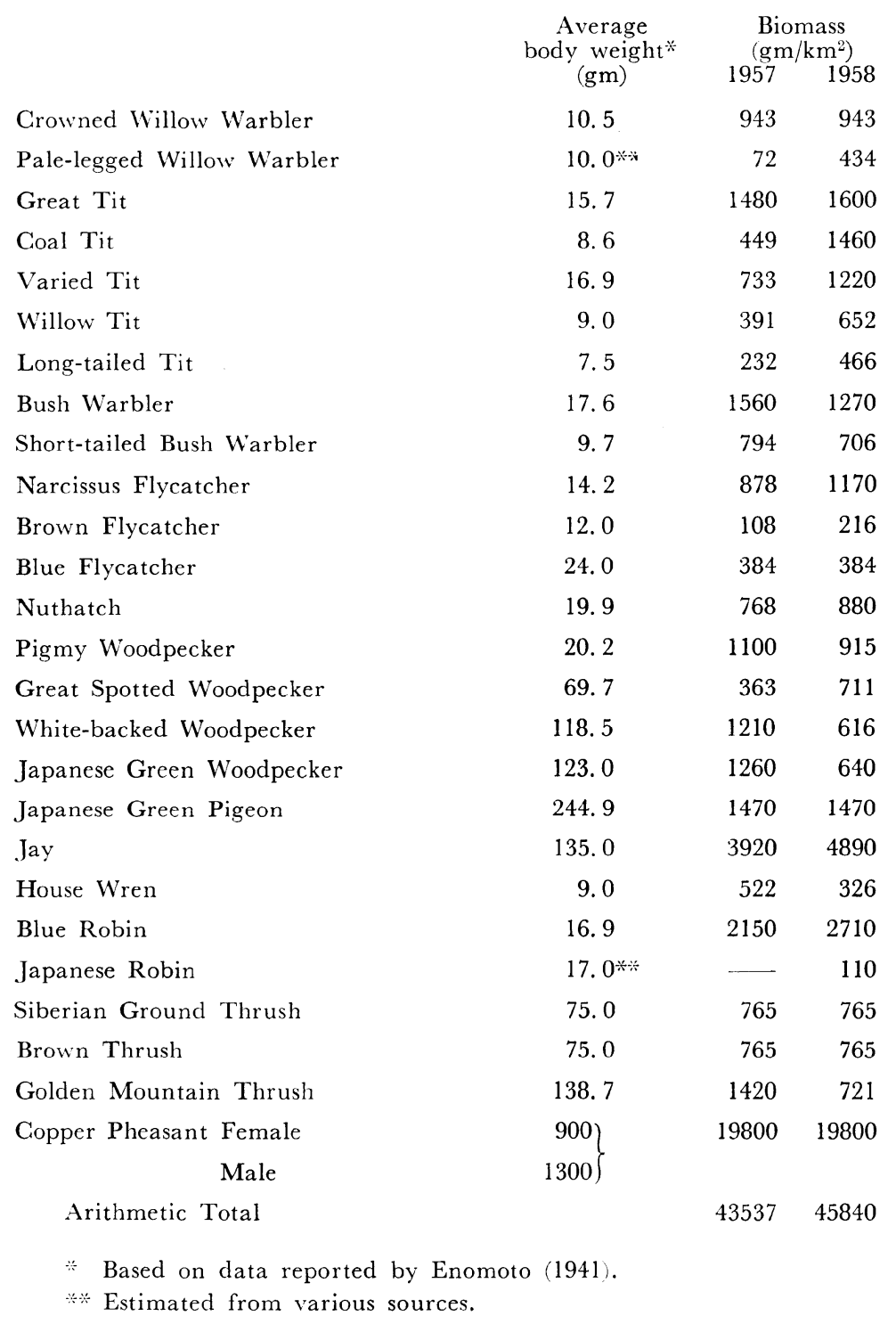

biomass of the community turns out to be much higher than that of American forest bird communities. It is, however, not certain on what cause the difference is based.

c) Distribution Pattern of Some Species

Since this mountain forest, like almost all other natural forest of Japan, inevitably shows some marked habitat patterns and since species composition and size of each 
species population are different in different stands, a study on habitat selection of each species must be made in the investigation of the forest bird community. These patterns of distribution are caused by the patterns of habitat and the habitat preference of each species of birds, and this and the following section of this paper are devoted to a reconnaissance of the problem in the broad-leaved deciduous forest.

Some species in the area showed pattern of distribution corresponding to pattern of habitat, either topographic or vegetational or both. Those species that showed clear pattern were Bush Warbler, Cettia diphone, Short-tailed Bush Warbler, Urosphena squameiceps, Blue Robin, Erithacus cyane, House Wren, Troglodytes troglodytes, and Pale-legged Willow Warbler, Phylloscopus tenellipes, all of which were shrub-dwellers or ground nesters.

Bush Warbler was found only in those places where bamboo-grass grew densely. This species is a typical bush-dweller and usually found in dense thicket of shrubs, regardless of plant communities and of whether it is in or out of forest. As there was no dense bush except bamboo-grass thicket in the census area, the species might be restricted there. Short-tailed Bush Warbler also dwelt only those places where bamboo-grass grew, but it was found mainly near steep gullies and, hence, in less dense thicket, probably for the nest site requirement. Blue Robin dwelt also in thicket of bamboo-grass and was found in those places where saplings grew densely, too. These three species were not found in gullies, rocky ridges and where neither bamboo-grass nor dense undergrowth grew.

In contrast with these species House Wren and Pale-legged Willow Warbler dwelt in or near small ravine, gullies, rocky ridges and in steep rocky slopes, perhaps for the nest site requirement. It seemed that although these two species did not avoid places where bamboo-grass grew, places which they usually haunted were lacking of it or had sparse growth of it.

Of the other species, some showed less clear pattern of distribution. Blue Flycatcher, Muscicapa cyanomelana, was found only at steeper slopes and some large gullies. Members of genus Turdus and Copper Pheasant seemed to shun dense thicket of bamboo-grass. Crowned Willow Warbler, Phylloscopus occipitalis, Narcissus Flycatcher, Muscicapa narcissina, Varied Tit, Parus varius, and Nuthatch, Sitta europeae, appeared to avoid where Tsuga Sieboldii was dominant. But there remained some questions for the distribution pattern of these species.

And in 1958 a pair of Japanese Robin, Erithacus akahige, was found in the uppermost part of the census area, about $1200 \mathrm{~m}$ above sea level. It seemed to be an accident to find this species in the census area, for usually it dwells above 1400$1500 \mathrm{~m}$ in altitude in central Japan. In the deciduous forest in this region this species was always found in the dense thicket of bamboo-grasses near ravines and torrents above $1400 \mathrm{~m}$. 
d) Feeding Niches and Feeding Groups

As noted previously, food nexus is important as the pathway of the flow of matter and energy in a community. Since each species of birds has prefered feeding places, the spatial distribution of the feeding places constitutes an important structure in the forest community. For considering the community structure it is necessary to take into account the horizontal distribution as well as the vertical one of the feeding places of the species.

Vertical zonation as the structure of the forest bird community has been noted since some years ago. Dunlavy (1935) divided a chaparral vegetation into four "phyto-vertical" zones and made each species of birds belong to each zone by species specific refuge at danger. Colquhoun and Morley (1943) studied the vertical zonation of feeding niche of woodland birds in the winter. Hartley (1953) and Gibb (1954) made extensive studies on the feeding niche of English titmice and related species. Salt (1953 and 1957) analysed the forest avifauna by grouping the birds based on food and feeding habit. In these studies the structure was only means by which comparison of different bird communities was made or the degree of segregation between related species was measured. But, as pointed out by Elton and Miller (1954), "the spatial distribution of species network" constitutes a very important structure in the community, which will be described below. The structure based on feeding places of each species was not rigid but temporaly one, for feeding places of birds vary with not only seasons but also breeding stages, and is on intimate relation with the environment.

Observations of feeding places of each species were made together with census works. It is desirable to make an extensive count and to analyse the data statistically as made by Hartley (1953) and Gibb (1954), but here the data were so few that it was impossible to determine strictly the feeding place of each species. Therefore, several species were treated in groups, and 27 species were divided into 7 or 8 groups, as follows.

"Leaf" group: Crowned Willow Warbler and Pale-legged Willow Warbler.

These two species fed mainly among leaves in tree crown and rarely in the shrub layer. (A pair of Growned Willow Warbler accompanied by fledglings was observed feeding in the shrub layer. But it was uncertain whether every family flock of this species showed such behaviour.)

"Twig and Leaf" group: Great Tit, Parus major, Varied Tit, Coal Tit, Parus ater, Willow Tit, Parus atricapillus, and Long-tailed Tit, Aegithalos caudatus.

These five species had main feeding places at twigs and leaves of trees and shrubs (but rarely of bamboo-grasses). But since these species except Long-tailed Tit often fed on branches, limbs and trunks of trees, their feeding places overlapped with 
those of "Leaf" and "Branch and Trunk" groups. The feeding places of these species except Varied Tit seemed to resemble those of English tits. Great Tit had the widest range of the feeding places from among leaves to the ground. Coal Tit and Willow Tit were less often seen at the ground and trunks and more often at branches and twigs than Great Tit was. The height of the feeding places seemed to be higher in Coal Tit than in Willow Tit. Long-tailed Tit almost restricted itself among leaves and at twigs irrespective of the height above the ground. The largest of these, Varied Tit, was similar to Great Tit in feeding places and feeding habit, but was more resembling to Nuthatch than Great Tit, and was less often seen at the ground and more at the tips of twigs. (cf. Hartley, 1953 ; Gibb, 1954).

In Japanese larch, Larix leptolepis, plantation in the footzone of Mt. Fuji in in central Japan, Royama (Personal communication) observed that Great Tit usually fed at high twigs and needles in breeding season, but those who were rearing nestlings searched the food for nestlings at low shrub and herb layers. Such a change in feeding habit according to the stages of breeding might be found in the forest studied, but present observations could not reveal it.

"Bush" group: Bush Warbler and Short-tailed Bush Warbler.

These two species fed only in the thicket of bamboo-grass, as mentioned in previous section. They were not found feeding on the ground, although the former was observed rarely feeding on the ground in the winter quarters. As mentioned before, these species do not shun the shrubs and tall herbs but there is no dense thicket of them in the census area.

"Air" group: Narcissus Flycatcher, Brown Flycatcher, Muscicapa latirostris, and Blue Flycatcher.

These three species usually chased after and fed on passing insects. But they often fed on leaf-caterpillars and spiders. The feeding places of these species were partially segregated. Narcissus Flycatcher fed beneath and in the forest canpy, Brown Flycatcher in and above the forest canopy and Blue Flycatcher above and by the forest canopy. Blue Flycatcher, and partly Brown Flycatcher, have a character of forest edge species. Usually these two species do not dwell in the dense forest on the flatland, and Brown Flychatcher appears in the somewhat sparse forest and Blue Flycatcher by mountain torrents. Probably because of steepness of this region these three species were found together.

(Besides these House Martin, Delichon urbica, may be added to this group. Although it was not found in the census area, two colonies of House Martin exist about $2 \mathrm{~km}$ distant from the census area.)

"Branch and Trunk" group: Nuthatch, Pigmy Woodpecker, Dendrocopos kizuki, Great Spotted Woodpecker, White-backed Woodpecker and Japanese Green Woodpecker. 
These five species fed mainly on branches, limbs and trunks. But these species except Pigmy Woodpecker sometimes fed at fallen tree trunks. Pigmy Woodpecker mainly fed at branches and trunks about $10 \mathrm{~cm}$ or less in diameter and Great Spotted and White-backed Woodpeckers at those about $10 \mathrm{~cm}$ or more in diameter, though Pigmy Woodpecker was often seen feeding at larger tree trunks. Curiously, Japanese Green Woodpecker, the largest of them, climbed up to more slender branches and trunks than smaller Great Spotted and White-backed Woodpeckers did.

"Canopy" group: Jay, Japanese Green Pigeon and Hymalayan Guckoo.

These three species were found only in the forest canopy. They were so shy that feeding activity was not observed. But it seemed probable that they were feeding in the tree crown in the breeding season, though Jay was sometimes seen feeding on the ground in the winter.

"Ground" group: House Wren, Blue Robin, Japanese Robin, Siberian Ground Thrush, Turdus sibiricus, Brown Thrush, Turdus chrysolaus, Golden Mountain Thrush, Turdus dauma, and Copper Pheasant. (First three species may be separated as "Small Ground" group from the last four species which may be grouped and named "Large Ground" group.)

These seven species fed on the ground. House Wren was found feeding at crevices and spaces among exposed rocks in the gullies, ravine and rocky ridges, and often fed under fallen tree trunks and exposed roots near gullies and rocky ridges. Blue Robin and Japanese Robin fed on ground only in the thicket. The other four species seemed to feed on the ground where the sparse or no thicket grew, as mentioned previousely.

The number of individuals and the biomass of each feeding group were shown in Table 8. It was evident that "Ground" group predominate other groups in biomass.

\section{A tentative estimation of the food consumption of the community}

The evaluation of the influence of each species population of birds on the populations of other organisms and of the relative importance of each species population in the forest have been attempted by various authors. It can be made only when these influences are determined quantitatively. These influences can be determined by different ways according to the different point-of-view. Here they will be measured by the food consumption and the energy budget from the point-of-view that most of these influences operate by the way of food relation and that energy flow is one of the fundamental processes in the community.

Salt (1957) used a relative value to compare the influences of species populations of birds. He multiplied the number of individuals of each species by 0.7 power of 
药

戛

苞

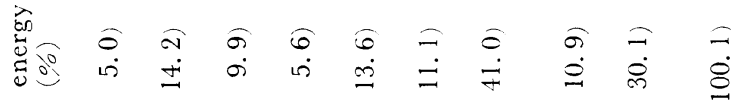

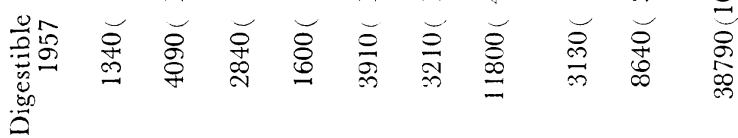

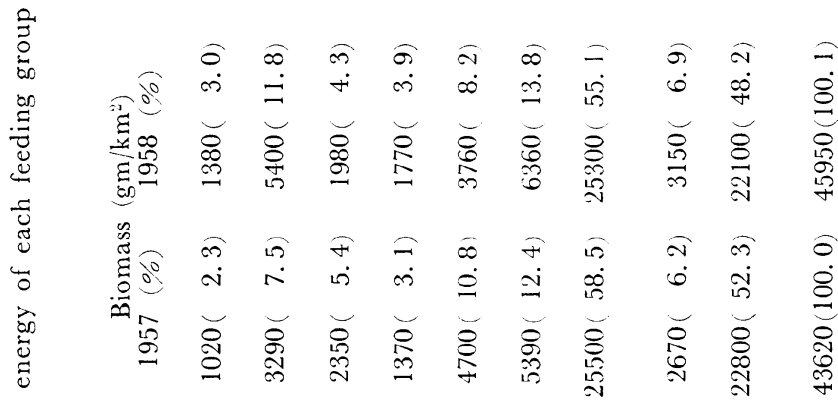

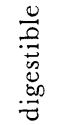

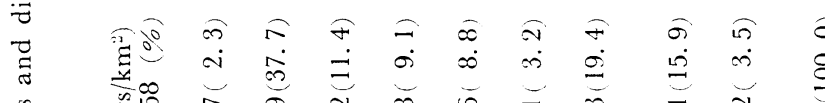

范

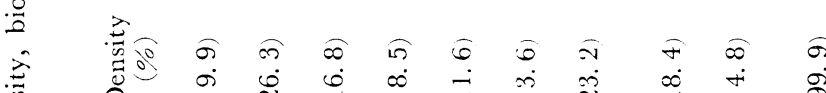

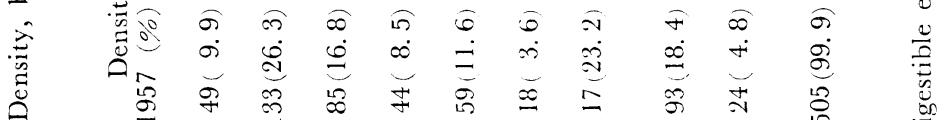

$\infty$

$\frac{\sqrt{\frac{1}{0}}}{\frac{0}{0}}$

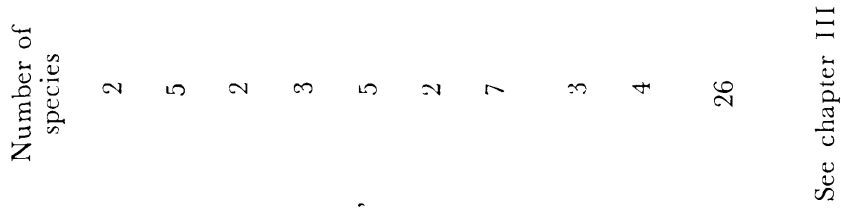

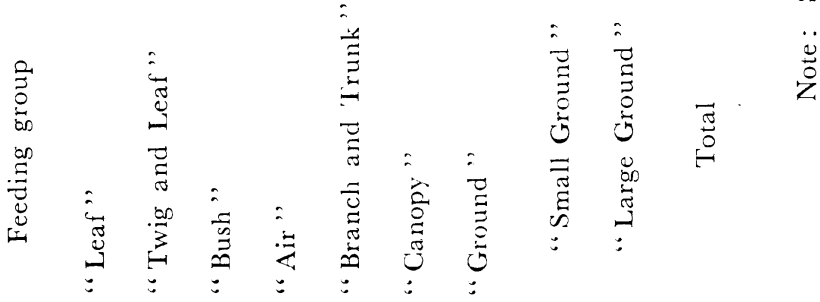


its body weight and called these values the "consuming biomass". Although he was right in considering that the relative importance of each species had to be expressed by food consumption or energy intake, he thought that their precise figure could be determined at present only when the environmental temperature and species difference of temperament were known, and was satisfied to express them as the consuming biomass, a relative value. Relative value may be good enough to compare the influence of bird populations one another. But it is more important to determine their influences on the other organisms and it is impossible to do so by relative values. It is of considerable importance in the studies of the forest to know the actual figures of food consumption and energy budget of each species population, even if these may be very crude at present. And even though the environmental temperatures and species difference of temperament were known, the precise figure of them would not have been know unless the features of population dynamics is known for each species population living there. In fact it may be so, but it seems a sort of agnosticism for us. Therefore, these values were calculated here, though they were very crude.

As mentioned in previous section, it is possible to estimate the digestible energy of captive birds and it can be assumed safely that the digestible energy of wild birds will be about $130-150 \%$ of that of captive bird. Starting from this assumption the food consumption of wild bird population was calculated on the assumptions related below.

Assuming that each species of birds in captivity requires the energy represented by the equation $\mathrm{Y}=2.03 \mathrm{~W}^{0.706}$, where $\mathrm{Y}$ is the digestible energy in Kical per bird per day and $\mathrm{W}$ the body weight in gm fresh weight, and that the wild birds require the energy $30 \%$ more than captive birds do, the energy digested by each species population could be given by multiplying the value thus determined by the number of individuals.

The digestive coefficient was assumed to be $80 \%$ for every food organism. As mentioned previously, the digestive coefficient of food organisms except adult insects and spiders is about $80 \%$ or more, and that of adult insects and spiders, and perhaps of centipeds and millipeds, is probably less than $70 \%$. So, the value $80 \%$ would be reasonable.

The calorific value of food organisms was assumed to be $5 \mathrm{Kcal}$ per gm dry weight in average. In general, animal food has the calorific values of 5-6 Kical per gm dry weight and plant food $4-7 \mathrm{Kcal}$ per gm dry weight, and it is different in different organisms. As the food habit of each species in the area was unknown, the value $5 \mathrm{Kcal}$ per gm dry weight was assumed to be a reasonable value.

And water content of animal food was assumed to be $85 \%$. Since water content of plant food was about $90 \%$ for buds and fruits and about $10 \%$ for seeds and nuts, 
the average value for plant food was not able to be assumed.

The results of calculations were shown in Table 9. Of the species listed in Table 9 Copper Pheasant and Japanese Green Pigeon are herbivorous and Jay is omnivorous,

Table 9. Digestible energy and food consumption of each species population

\begin{tabular}{|c|c|c|c|c|c|c|}
\hline \multirow{3}{*}{ Crowned Willow Warbler } & \multirow{2}{*}{\multicolumn{2}{|c|}{$\begin{array}{l}\text { Digestible energy } \\
\left(\text { Kcal/day } / \mathrm{km}^{2}\right) \\
1957 \quad 1958\end{array}$}} & \multirow{2}{*}{\multicolumn{2}{|c|}{$\begin{array}{l}\text { Food consumption } \\
\left(\mathrm{gm} \mathrm{DW} / \mathrm{day} / \mathrm{km}^{2}\right) \\
1957\end{array}$}} & \multicolumn{2}{|c|}{$\begin{array}{c}\text { Animal Food } \\
\text { consumption } \\
\left(\mathrm{kg} \mathrm{FW} / \text { day } / \mathrm{km}^{2}\right)\end{array}$} \\
\hline & & & & & & 1958 \\
\hline & 1240 & 1240 & 310 & 310 & 2.07 & 2.07 \\
\hline Pale-legged Willow Warbler & 97 & 581 & 24.1 & 145 & 0.161 & 0.967 \\
\hline Great Tit & 1740 & 1870 & 435 & 468 & 2.90 & 3. 12 \\
\hline Coal Tit & 631 & 2050 & 158 & 513 & 1.05 & 3.42 \\
\hline Varied Tit & 841 & 1400 & 210 & 350 & 1.40 & 2.33 \\
\hline Willow Tit & 542 & 904 & 136 & 224 & 0.907 & 1. 49 \\
\hline Long-tailed Tit & 339 & 679 & 84.8 & 170 & 0.566 & 1. 13 \\
\hline Bush Warbler & 1770 & 1450 & 443 & 363 & 2.95 & 2.42 \\
\hline Short-tailed Bush Warbler & 1070 & 951 & 268 & 238 & 1.79 & 1.59 \\
\hline Narcissus Flycatcher & 1060 & 1410 & 265 & 353 & 1.77 & 2.35 \\
\hline Brown Flycatcher & 137 & 247 & 34.3 & 65.8 & 0.229 & 0.457 \\
\hline Blue Flycatcher & 399 & 399 & 99.8 & 99.8 & 0.666 & 0.666 \\
\hline Nuthatch & 843 & 965 & 211 & 241 & 1.41 & 1.61 \\
\hline Pigmy Woodpecker & 1200 & 999 & 300 & 250 & 2.00 & 1.67 \\
\hline Great Spotted Woodpecker & 275 & 540 & 68.8 & 135 & 0.459 & 0.900 \\
\hline White-backed Woodpecker & 782 & 399 & 196 & 99.8 & 1.31 & 0.666 \\
\hline Japanese Green Woodpecker & 805 & 410 & 201 & 103 & 1.34 & 0.687 \\
\hline Japanese Green Pigeon & 769 & 769 & 192 & 192 & $\ldots$ & $\ldots$ \\
\hline Jay & 2440 & 3040 & 610 & 760 & 4.07 & 5.07 \\
\hline House Wren & 724 & 452 & 181 & 113 & 1.21 & 0.754 \\
\hline Blue Robin & 2460 & 3100 & 615 & 775 & 4.10 & 5.17 \\
\hline Japanese Robin & - & 127 & - & 31.8 & - & 0.212 \\
\hline Siberian Ground Thrush & 568 & 568 & 142 & 142 & 0.947 & 0.947 \\
\hline Brown Thrush & 568 & 568 & 142 & 142 & 0.947 & 0.947 \\
\hline Golden Mountain Thrush & 877 & 447 & 219 & 112 & 1.46 & 0.747 \\
\hline Copper Pheasant Female & 2890 & 2890 & 723 & 723 & $\ldots$ & $\ldots$ \\
\hline Male & 3740 & 3740 & 935 & 935 & $\ldots$ & - \\
\hline Arithmetic Total & 28753 & 32222 & 7203.8 & 8056.8 & 35.712 & 41.390 \\
\hline $\begin{array}{l}\text { Note: Digestible ene } \\
\quad \mathrm{Y}=2.03 \mathrm{~W}^{0.706} .\end{array}$ & above is & $130 \%$ of & the valu & e calculat & t by th & equat \\
\hline $\begin{array}{l}\text { Food consumption is } \\
\text { 1) digestive coeffi } \\
\text { 2) calorific values } \\
\text { 3) water content } \\
\text { 4) all species exc }\end{array}$ & $\begin{array}{l}\text { on the } \\
1 \text { food a } \\
\text { d items } \\
\text { food is } \\
\text { se Green }\end{array}$ & $\begin{array}{l}\text { ollowing } \\
\text { e the sam } \\
\text { re } 5.0 \mathrm{Kc} \\
5 \% \text { and } \\
\text { Pigeon ar }\end{array}$ & $\begin{array}{l}\text { assumptio } \\
\text { al/gm dry }\end{array}$ & weight, & & \\
\hline
\end{tabular}


and the other species are mainly carnivorous in breeding season. But, for convenience sake, Jay was regarded as carnivores in calculation of fresh food consumption. Total food consumption was $7.2 \mathrm{~kg}$ dry weight per square $\mathrm{km}$ per day in 1957 and $8.0 \mathrm{~kg}$ dry weight per square $\mathrm{km}$ per day in 1958. Total animal food consumption was $35.7 \mathrm{~kg}$ fresh weight per square $\mathrm{km}$ per day in 1957 and $41.4 \mathrm{~kg}$ fresh weight per square $\mathrm{km}$ per day in 1958. It is evident from the table that in this community Copper Pheasent, Blue Robin, Jay, Great Tit and Coal Tit (in 1958) are the most influent species.

As the body weight of adult birds are approximately constant, it can be presupposed that the digestible energy is nearly equal to the energy consumed and dissipated by the bird. Thus, total energy dissipated by this bird community was $28.7 \times 10^{3}$ Kcal per square $\mathrm{km}$ per day in 1957 and $32.2 \times 10^{3} \mathrm{Kcal}$ per square $\mathrm{km}$ per day in 1958.

These values of each feeding group were shown in Table 8 together with the density and biomass. The difference between 1957 and 1958 is considered to be ascribable mainly to the remarkable increase of Coal Tit in 1958. Other species are nearly equal in both years. It is remarkable that "Ground" group is the most influent one both in biomass (about 55\%) and in food consumption (about 40\%).

The food consumption and dissipated energy estimated above were, of course, those of breeding pairs only. The presence of polygamous species and unmated individuals would make increase these values. And it was not considered here that there would be many nestlings and fledglings reared by these pairs and that the adult population would decrease in the breeding season. The proportion of unmated individuals to breeding pairs, the brood size and the mortality of adults, nestlings and fledglings would be different in different species. So, without corrections on them the study of the influences of birds on the forest and of the relative importance of each species population is incomplete. But since the study of the population dynamics of Japanese birds have not been performed at all by now, these corrections could not be made here. Nevertheless, it was believed that the estimation made is a contribution to the study of the forest, since there have been no quantitative study on food relations of the bird community in the forest.

The biomass of macrofauna in $\Lambda_{0}$ layer of soil collected by Kitazawa (data unpublished) in the census area in July were $0.133 \mathrm{gm}$ dry weight per 0.25 square $\mathrm{m}$ under the thicket of bamboo-grasses, $0.059 \mathrm{gm}$ dry weight per 0.25 square $\mathrm{m}$ under sparse shrub and 0.014 gm dry weight per 0.25 square $m$ in gravel soil on steeper slope, or 532, 236 and $56 \mathrm{~kg}$ dry weight per square $\mathrm{km}$, respectively. And that of ground surface in the beech forest of Ozegahara, placed at north-eastern central Japan (Kitazawa et al., 1954), were $2.12 \mathrm{gm}$ fresh weight per 0.25 square $\mathrm{m}$ in May and $2.96 \mathrm{gm}$ fresh weight per 0.25 square $\mathrm{m}$ in July, or 8.48 and 11.84 ton fresh 
weight per square $\mathrm{km}$, respectively. The animal food consumption of "Ground" group, $1.3 \mathrm{~kg}$ dry weight per square $\mathrm{km}$ per day or $8.7 \mathrm{~kg}$ fresh weight per square $\mathrm{km}$ per day, was about $1 / 100$ to $1 / 1000$ of these values except in rocky area.

Möller, Müller and Nielsen (1954) studied the dry matter production of beech, Fagus sylvatica, and estimated that gross production was 21.4 ton dry weight per ha per year and respiration 10.1 ton dry weight per ha per year in 85-year-old beech forest. Assuming that one third of them were produced and respired in the breeding period of the bird, 100 days, gross production was about $7.1 \times 10^{2}$ ton dry weight per square $\mathrm{km}$ per 100 days and respiration about $3.4 \times 10^{-}$ton dry weight per square $\mathrm{km}$ per 100 days. So, the food consumption of the bird community, $7.2-8.0 \mathrm{~kg}$ dry weight per saure $\mathrm{km}$ per day, was about $1 / 1000$ of gross production and about 1/500 of net production. Gross production of $7.1 \times 10^{2}$ ton dry weight corresponds about $28.5 \times 10^{4} \mathrm{Kcal}$ and respiration of $3.4 \times 10^{2}$ ton dry dry weight about $13.5 \times 10^{-} \mathrm{Kcal}$. So the energy dissipated by the bird community, 28.7-32.2 $\times 10^{3}$ Kcal per square $\mathrm{km}$ per day, was about $1 / 1000$ of the energy captured by beech and about $1 / 500$ of the energy dissipated by beech.

\section{Acknowledgement}

The author should like to express his hearty thanks to $\mathrm{Mr}$. H. Kurihara and some other members of Water-source Forestry Office, Tokyo Metropolitan Waterworks and Sewerage Bureau, without whose kind assistance the field work would not have been performed. He is grateful to Profs. K. Hougetsu and Y. Kitazawa of Tokyo Metropolitan University, under whose guidance this work has been done, to Mrs. M. Nakamura for technical assistance, and the members of the Ecological Laboratory at Tokyo Metropolitan University for the discussion and advices.

\section{Summary}

1. The ecological survey of a breeding bird community was carried out in the broad-leaved deciduous forest of Chichibu-Tama National Park in central Japan, and the food consumption of each species population was estimated by a procedure based on the feeding experiments of captive birds.

2. The fecding experiments were carried out on Uroloncha domestica, Cyanopica cyanus japonica and Corvus corone orientalis. The food intake was 2.7 and $2.4 \mathrm{gm}$ dry weight per bird per day or 11.1 and $9.8 \mathrm{Kcal}$ per bird per day in female and male Uroloncha, respectively, fed on great millet. It was 11.8 and $15.2 \mathrm{gm}$ dry weight per bird per day or 57.2 and $72.8 \mathrm{Kcal}$ per bird per day in Cyanopica fed on a paste food and sikworm, respectively. Corius fed on horse-mackerel consumed the food averaging $38.2 \mathrm{gm}$ dry weight per bird per day or $221.4 \mathrm{Kcal}$ per bird per day. 
3. The faeces output was 0.34 and $0.31 \mathrm{gm}$ dry weight per bird per day or 1.18 and $1.08 \mathrm{Kcal}$ per bird per day in female and male Uroloncha, 7.18 and $4.25 \mathrm{gm}$ dry weight per bird per day or 27.02 and $14.51 \mathrm{Kcal}$ per bird per day in Cyanopica fed on a paste food and sikworms, and $15.3 \mathrm{gm}$ dry weight per bird per day or 41.4 Kcal per bird per day in Corvus.

4. The interspecific comparison of digestible energy was made on available data, and the relation between digestible energy and body weight was discussed. It was suggested that the logarithm of digestible encrgy was roughly proportional to the logarithm of body weight according to the equation $Y=2.03 \mathrm{~W}^{0.706}$.

5. The digestive coefficient of various food organisms was also compared and some discusssions were made.

6. The available data on the food consumption of the wild birds were examined with respect to that of captive birds and the relation between food intake and body weight.

7. The breeding bird census was carried out by the method of territory mapping on a belt-shaped plot, which was $2750 \mathrm{~m}$ long, in 1957 and 1958.

8. Number of species was 28 in 1957 and 29 in 1958. The total density was $505+$ pairs per square $\mathrm{km}$ in 1957 and $636+$ pairs per square $\mathrm{km}$ in 1958 . The most abundant species was Erithacus cyane, followed by Parus major, Phylloscopus occipitalis and Parus ater (only in 1958).

9. The total biomass was about $45 \mathrm{~kg}$ per square $\mathrm{km}$ in both years, much higher than that of similar forest of eastern North America.

10. The pattern of distribution corresponding with the pattern of physiographic and/ or vegetational feature of the habitat in the census area was seen in some species.

11. Accoriding to the feeding niches observed, 26 species were divided into 7 or 8 feeding groups, and the feeding niches of some species were described in some details.

12. The food consumption of every species population in the forest was calculated on the several assumptions. The group which consumed the food organisms most abundantly was "Ground" group and those species that consumed the food much more than others were Phasianus soemmerringii, Erithacus cyane and Garrulus glandarius.

13. Some discussions based on these calculated values were made.

\section{References}

Brody, S. (1945) Bioenergetics and Growth. Washington.

Colquhoun, M. K. and A. Morley (1943) Vertical zonation in woodland bird communities. J. Anim. Ecol., 12 : 75-81.

Davis, E. A., Jr. (1955) Seasonal changes in the energy balance of the English Sparrow. Auk, 72: $385-411$.

Drinnan, R. E. (1957) The winter feeding of the Oystercatcher (Haematopus ostralegus) on the 
edible cockle (Cardium edule). J. Anim. Ecol., 26: 441-469.

(1958) Observations on the feeding of the Oystercatcher in captivity. Brit. Birds, 51: $139-149$.

Dunlavy, J. C. (1935) Studies on the phyto-vertical distribution of birds. Auk, 52: 425-431.

Elton, C. S. and R. S. Miller (1954) The ecological survey of animal community. J. Ecol., 42: 460496.

Enomoto, Y. (1941) Yacho Bin-ran, vol. 2. Osaka.

Fitch, H. S., F. Swensen and D. R. Rillotson (1946) Behavior and food habits of the Red-tailed Hawk. Condor, 48: 205-237.

Gibb, J. (1954) Feeding ecology of tits, with notes on Treecreeper and Goldcrest. Ibis, 96: 513543.

(1956) Food, feeding habits and territory of the Rock Pipit, Anthus spinolettu. Ibis, 93 : $506-530$. 215 .

Hartley, P. H. T. (1953) An ecological study of the feeding habits of the English titmice. I. Anim. Ecol., 22 : 261-288.

Kendeigh, S. C. (1944a) Effect of air temperature on the rate of energy metabolism in the English Sparrow. J. Exp. Zool., 96: 1-16.

(1944b) Measurement of bird population. Ecol. Monogr., 14: 68-106.

(1949) Effect of temperature and season on energy resources of the English Sparrow. Auk, 66: 128-153.

Kitazawa, Y., H. Kurasawa and T. Takada (1954) Animal ecology of Ozegahara Moor and ad jacent districts. In "Scientific Researches of the Ozegahara Moor", p. 625-680. Tokyo.

Lack, D. (1954) The Natural Regulation of Animal Numbers. Oxford.

Macfadyen, A. (1957) Animal Ecology: aims and methods. London.

Maeda, T. and J. Yoshida (1952) Studies on the vegetation of Chichibu Mountain Forest (II). The plant communities of the temperate mountain zones. Bulletin of the Tokyo University Forest. No. 42.

Möller, C. M., D. Müller and J. Nielson (1954) Graphic presentation of dry matter production of European Beech. Det Forstlige Forsgsvaesen i Denmark, 31 (3): 327-335.

Nice, M. M. (1938) The biological significance of bird weight. Bird-Band., 9: 1-11.

Pynnönen, A. (1939) Beiträge zur Kenntnis der Biologie finnischer Spechte (I). Ann. Soc. Zool.-Bot. Fenn. "Vanamo", 7: 1-166.

Rautenberg, W. (1957) Vergleichende Untersuchungen über den Energiehaushalt des Bergfinken (Fringilla montifingilla L.) und des Haussperlings (Passer domesticus L.). J. Ornithol., 98 : 36-64.

Salt, G. W. (1953) An ecologic analyses of three California avifauna. Condor, 55: 258-273.

(1957) An analysis of avifauna in the Tenton Mountains and Jackson Hole, Wyoming. Condor, 59: 373-393.

Seibert, H. C. (1949) Differences between migrant and non-migrant birds in food and water intake at various temperatures and photoperiods. Auk, 66: 128-153.

Turcek, F. J. (1948/51) A contribution to the function of forest bird population from the point-ofview of biocoenology and forest management. Aquila, 55/58: 53-73.

Wallgren, H. (1954) Energy metabolism of two species of the genus Emberiza as correlated with distribution and migration. Acta Zool. Fenn., 84: 1-110.

Watson, A. (1957) 'The behavior, breeding and food-ecology of the Snowy Owl, Nycted scandiaca. Ibis, 99 : 419-462.

Williams, A. B. (1936) The composition and dynamics of a beech-maple climax community. Ecol. Monogr., 6: 318-408.

Wing, L. W. (1956) Natural History of Birds. New York. 


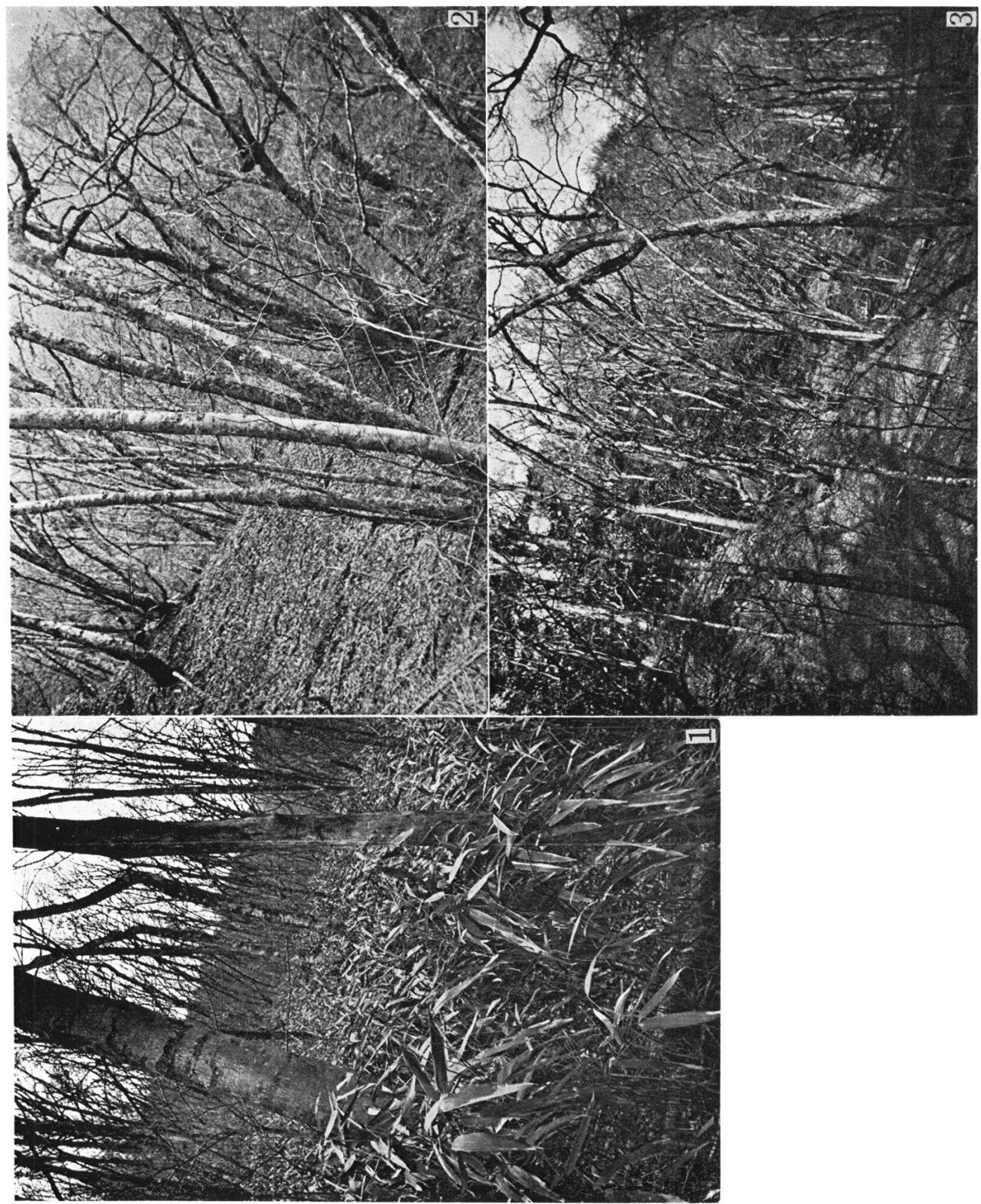

Plate I. Fig. 1 and Fig. 2 Typical features of the census area

Fig. 1, The place where bamboo-grass grows.

Fig. 2, The place where bamboo-grass does not grow.

Fig. 3 Shows the feature of the more gentle slope, where Quercus crispula grows. 

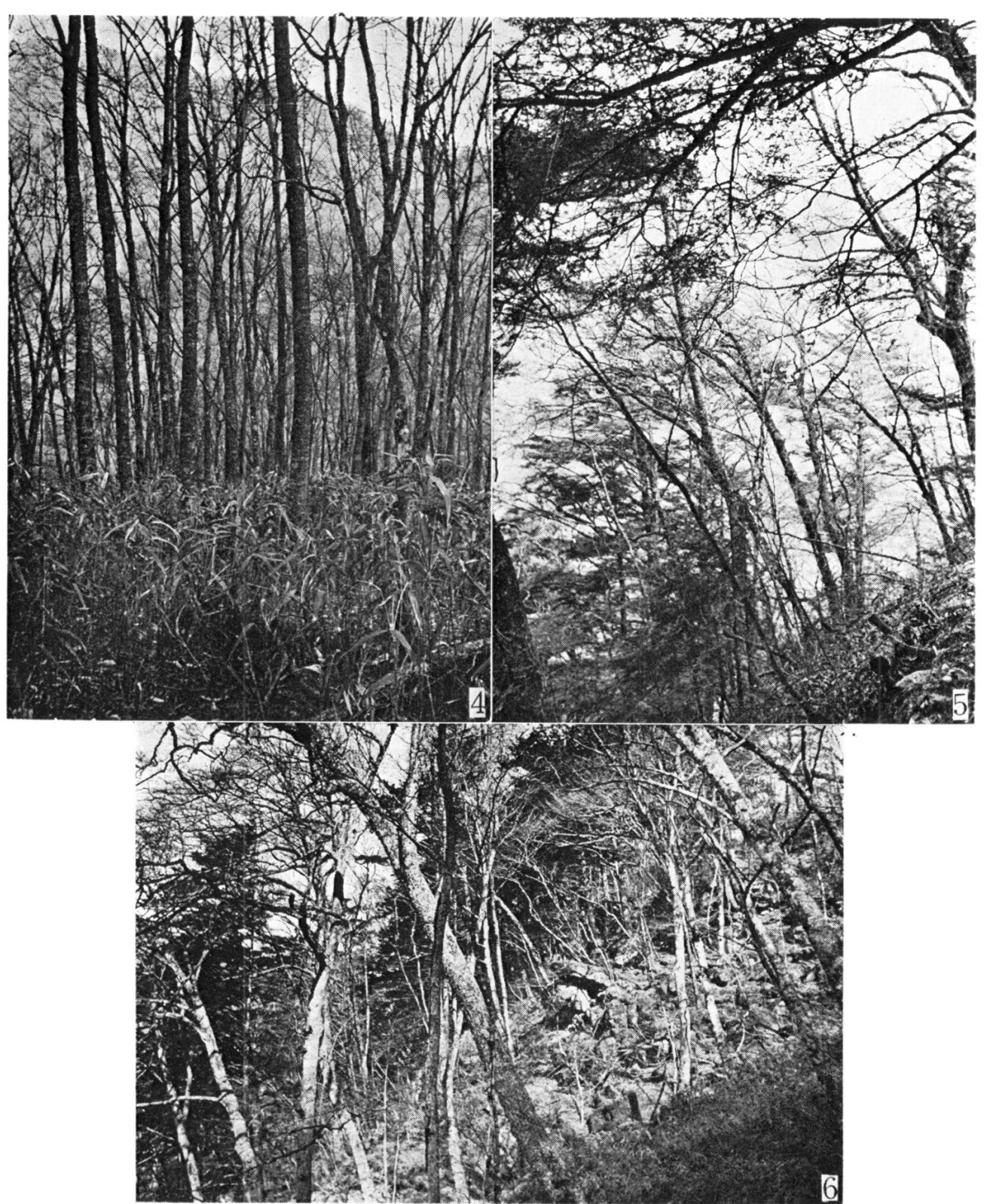

Plate 2. Fig. 4 The feature of the more gentle slope, where Retula spp. grow and the growth of bamboo-grass is rather poor.

Fig. 5 and Fig. 6 The features of the small ridges.

Fig. 5, The place where T'suga Sieboldii grows.

Fig. 6, The place where large rocks are exposed. The trees in the dark back scenery are Tsuga Sieboldii. 